\title{
Financial instruments entail liabilities: Ether, bitcoin, and litecoin do not
}

\author{
Evariest Callens ${ }^{1}$ \\ Financial Law Institute, Ghent University, Belgium
}

\section{A R T I C L E I N F O}

\section{Keywords:}

Financial instruments

Transferable securities

MiFID II

Intrinsic v. extrinsic asset value

Cryptocurrencies

Stablecoins

Bitcoin

Ether

Litecoin

Ripple

\begin{abstract}
A B S T R A C T
The financial assets that are subject to major EU financial legislation (i.e. (designated types of financial instruments) have traditionally been defined in a largely exemplary and circular manner. The recent proliferation of 'non-traditional' financial assets, such as cryptocurrencies and stablecoins, is increasingly challenging the viability of these pragmatic financial asset definitions. Through the analysis of the technologies and functionalities underpinning non-traditional financial assets, legal scholarship has aimed to categorize novel assets within the existing framework of financial asset definitions. Although a solid understanding of e.g. distributed ledger applications and cryptography appears a prerequisite for future policy and legislative interventions, contemporary EU financial legislation is mostly indifferent to the technologies on which financial assets may be wired. Categorizations based on the purposes that non-traditional assets may serve (i.e. payment, utility, and investment) are more relevant to financial law, but suffer from subjectivity because they depend on the asset usage by the asset holder. Against this backdrop, this paper proposes a novel systematization of non-traditional assets that is based upon the conceptual substructure of the assets within the scope of EU financial legislation. More specifically, this paper submits that, irrespective of underlying technologies and functionalities, all assets that are subject to major EU financial legislation have a conceptual common denominator: they entail the liability of an entity and, hence, have intrinsic value. The proposed categorization singles out a welldefined group of novel financial assets that is not subject to EU financial law (i.e. assets that only have extrinsic value). Different from functionality- and technology-based categorizations, the suggested approach allows to eradicate some ambiguities that are present in the existing taxonomies. By exploring the conceptual common denominator of the financial assets that are subject to EU financial legislation, this paper aims to foster debate on the circular and exemplary character of financial asset definitions in EU financial legislation in general and the relation of these definitions to novel types of financial assets in particular.
\end{abstract}

@ 2020 Evariest Callens. Published by Elsevier Ltd. All rights reserved.

E-mail address: Evariest.Callens@UGent.be

${ }^{1}$ PhD Candidate, Financial Law Institute, Ghent University; Visiting Researcher and Research Assistant, Harvard Law School 2019-2020 (BAEF Fellow). I am grateful to two anonymous referees, Simon Geiregat, Niels Rogge, Reinhard Steennot, Liselotte Van Coillie, and the participants at the European Banking Institute Young Researchers Group Virtual Workshop Session (July 2020) for helpful comments on earlier drafts of this paper. 


\section{Introduction}

\subsection{Intrinsic and extrinsic asset value}

In line with common parlance and financial markets jargon, this paper employs the term 'asset' to refer to any tangible or non-tangible item that has value (e.g. gold or contractual rights). ${ }^{2}$ The value of an asset may be derived from determinants that are either intrinsic or extrinsic to the considered asset.

The intrinsic determinants of asset value are the parameters that define the very nature of an asset and from which the asset holder may directly or indirectly derive utility, even if there exists no market demand for the asset. For instance, soybeans and gold may each provide direct utility to the asset holder (respectively through e.g. food consumption and usage in smartphones), even if no one is willing to buy these assets from the asset holder. Similarly, but indirectly, plain vanilla government bonds may provide utility to the bondholder, even in absence of prospective buyers in the bond market. Indeed, a government bond entails the bondholder's legally enforceable right to receive a predefined amount of funds from the government at the bond's maturity. The received funds may in turn provide utility to the bondholder and, hence, a government bond has a certain intrinsic value. In the example of the government bond, the bondholder derives value from the contract through the bondholder's right vis-à-vis the government and the corresponding liability ${ }^{3}$ of the government to perform vis-à-vis the bondholder. ${ }^{4}$ Naturally, from the perspective of the issuing government, the contract cannot be regarded as an asset, since it has a negative net value for the government. However, in order not to compromise legibility and since right and liability are in this context two sides of the same coin, I will hereinafter refer to these types of contracts as 'assets that entail the liability of an entity'. ${ }^{5}$

Besides intrinsic value, assets may also have extrinsic value. The extrinsic determinants of asset value are parameters that are exogenous to the asset, but nevertheless influence asset value. In a market economy, extrinsic asset value will result from the interaction between asset supply and demand. Hence, extrinsic asset value does not only account for intrinsic asset value, but also for e.g. the belief that others may at a future date want to acquire the asset at a favorable price.

\footnotetext{
${ }^{2}$ Hence, an item with no (intrinsic or extrinsic) value is not considered an asset.

${ }^{3}$ An obligation may also exist in absence of any entity deriving a right from it. Therefore, in the remainder of this paper, I will employ the term 'liability', which refers to the obligation of an entity towards another entity. This liability must not necessarily be a liability to deliver legal tender. It may e.g. also take the form of an obligation to refrain from action or to deliver services.

${ }^{4}$ See on the distinction between rights in personam and rights in rem: Peter Birks, 'Rights, Wrongs, and Remedies' (2000) 20 OJLS 1,21 . In some jurisdictions (e.g. Belgium), a creditor is technically the owner of his claim vis-à-vis his counterparty. However, the fact that a creditor has a right in rem on his claim does not alter the distinction between assets that have direct intrinsic value and assets that derive their intrinsic value from a right in personam.

${ }^{5}$ The word choice in this paper thus takes the perspective of the asset holder.
}

For instance, with regard to a scarce tangible asset (e.g. gold), the law of supply and demand may result in a total asset value that supersedes the intrinsic asset value. For assets that entail the liability of an entity (e.g. government bonds), the distinction between intrinsic and extrinsic value constitutes a fine line. Intrinsic value is the value that one may derive from the asset as a subject (i.e. the rights and liabilities that originate from the asset itself), whereas extrinsic value is the value that one may derive from the asset when it serves as the object (or single leg) in a two-legged transaction. For example, the rights and liabilities between a bondholder and the government that originate from the mere existence of a government bond (e.g. payment at maturity) contribute to the bond's intrinsic value. The degree to which the government-or any other entityagrees or commits to accept government bonds in exchange for e.g. services, goods, or legal tender contributes to the bond's extrinsic asset value.

In the gold example mentioned above, intrinsic and extrinsic asset value partly overlap. However, assets may also have extrinsic value in absence of any intrinsic value. The value of a bitcoin, for instance, is solely based on the law of supply and demand (see more in detail infra no. 2.1). If there were no market demand for bitcoins, it would be impossible for the holder of the coin to derive any value from it. In this respect, bitcoins fundamentally differ from gold, soybeans, government bonds, and other assets with intrinsic value.

\subsection{Thesis: assets that only have extrinsic value are not financial instruments}

The financial assets that are subject to major EU financial legislation (i.e. (designated types of) financial instruments) have traditionally been defined in a largely exemplary and circular manner. The recent proliferation of 'non-traditional' financial assets, such as cryptocurrencies and stablecoins, is increasingly challenging the viability of these pragmatic financial asset definitions. Through the analysis of the technologies and functionalities underpinning non-traditional financial assets, legal scholarship has aimed to categorize novel assets within the existing framework of financial asset definitions. Although a solid understanding of e.g. distributed ledger applications and cryptography appears a prerequisite for future policy and legislative interventions, contemporary EU financial legislation is mostly indifferent to the technologies on which financial assets may be wired. Categorizations based on the purposes that non-traditional assets may serve (i.e. payment, utility, and investment) are more relevant to financial law, but suffer from subjectivity because they depend on the asset usage by the asset holder. Against this backdrop, this paper proposes a novel systematization of non-traditional assets that is based upon the conceptual substructure of the assets within the scope of EU financial legislation. More specifically, this paper submits that, irrespective of underlying technologies and functionalities, all assets that are subject to major EU financial legislation have a conceptual common denominator: they entail the liability of an entity and, hence, have intrinsic value. The proposed categorization singles out a well-defined group of novel financial assets that is not subject to EU financial law (i.e. assets that only have extrinsic value). Different from functionality- and technology-based categorizations, the 


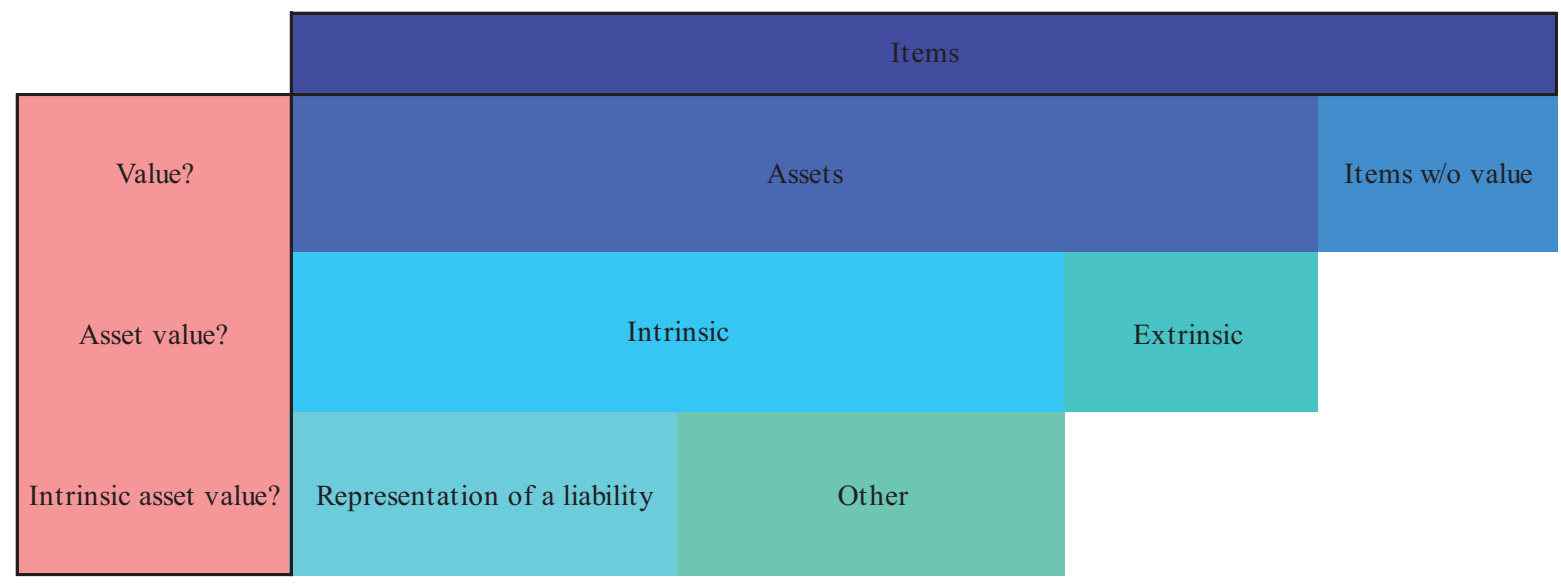

Fig. 1 - A value-based categorization of items (own work).

suggested approach allows to eradicate some ambiguities that are present in the existing taxonomies. By exploring the conceptual common denominator of the financial assets that are subject to EU financial legislation, this paper aims to foster debate on the circular and exemplary character of financial asset definitions in EU financial legislation in general and the relation of these definitions to novel types of financial assets in particular.

\subsection{Relation to existing literature on financial asset categorization}

The systematization of non-traditional assets proposed in this paper is no panacea for interpretational issues in relation to the financial assets within the scope of EU financial legislation. That is to say, to conclude that a given asset is governed by EU financial law, various parameters of the asset under consideration have to be assessed in light of the criteria set forth in the specific legislative act. The approach proposed in this paper focusses on the conceptual properties that the assets within the scope of EU financial law have in common and, hence, only establishes a minimum threshold. Accordingly, the observation that a certain asset entails the liability of an entity and thus has intrinsic value is insufficient to conclude that the asset is governed by EU financial law. However, the proposed categorization does shed light on an important group of assets that is definitely not covered by EU financial law: the assets that only have extrinsic value. As I will argue in the remainder of this paper, this negative demarcation is particularly useful for determining the qualification under contemporary EU financial law of many non-traditional financial assets, since many non-traditional financial assets only have extrinsic value.

The asset categorization proposed in this paper is complementary to the academic literature that has emerged in the wake of the development of non-traditional financial assets. In recent years, legal scholarship has extensively described the functioning of cryptography and distributed ledger technology. ${ }^{6}$ Such technology-centered perspective is helpful for

\footnotetext{
${ }^{6}$ See e.g. Tycho De Graaf, 'The Qualification of Bitcoins as Documentary Intangibles' (2019) 27 ERPL 1051; Simon Geiregat, 'Cryp-
}

gaining a deeper understanding of the technologies that may underpin financial assets, but is not necessarily useful for categorizing non-traditional assets within the existing framework of financial asset definitions in EU financial law. This is because the existing financial assets definitions in EU law are largely indifferent to the technologies on which financial assets may be wired. A second strand of literature has focused on the functionalities of non-traditional assets. In these classifications, authors essentially draw a distinction between nontraditional assets that are used for purposes of (i) payment; (ii) utility; or (iii) investment. ${ }^{7}$ Although such functional divi-

tocurrencies are (smart) contracts' (2018) 34 CLSR 1144; Renato Mangano, 'Blockchain Securities, Insolvency Law and the Sandbox Approach' (2018) 19 EBOR 715; Alexander Snyers and Karl Pauwels, 'ICOs in Belgium: down the rabbit hole into legal no man's land? Part 1' (2018) 29 ICCLR 483; Robby Houben, 'Bitcoin: there are two sides to every coin' (2015) TBH-RDC 139. Considering the technology-insensitive character of EU financial law, this paper presents a different narrative. Therefore, this paper will not discuss technologies that may underpin novel financial assets. Interested readers may wish to consult the relevant online resources or the synopses of these primary sources that have been published elsewhere. See for primary sources e.g. Libra Association Members, 'An Introduction to Libra' (White Paper, last revised 21 January 2020), available via https://libra.org/en-us/whitepaper; Satoshi Nakamoto, 'Bitcoin: A Peer-to-Peer Electronic Cash System' (2008), available via https://bitcoin.org/bitcoin.pdf, and the Bitcoin website (https://bitcoin.org/en/). Cryptography has existed for thousands of years. See e.g. Donald. Davies, 'A Brief History of Cryptography' (1997) 2:2 Information Security Technical Report 14,14 . To render double spending virtually impossible, cryptography can be combined with a distributed ledger technology application. Cf. Satoshi Nakamoto, 'Bitcoin: A Peer-to-Peer Electronic Cash System' (2008) 2, available via https://bitcoin.org/ bitcoin.pdf. Satoshi Nakamoto is most likely a pseudonym concealing the identity of one or more persons. The Bitcoin white paper was first released on Friday 31 October 2008 through the following link http://www.metzdowd.com/pipermail/cryptography/ 2008-October/014810.html.

${ }^{7}$ See e.g. European Commission, 'Consultation document on an EU framework for markets in crypto-assets' (December 2019) 3, available via https://ec.europa.eu/info/sites/info/ files/business_economy_euro/banking_and_finance/documents/ 2019-crypto-assets-consultation-document_en.pdf; FCA, 'Guid- 
sions are instructive and more helpful to financial law asset qualifications than technology-based taxonomies, they also suffer from drawbacks. First, non-traditional assets that have been conceived for one purpose (e.g. payment) may very well be used for another purpose (e.g. investment). ${ }^{8}$ Hence, in practice, asset classifications based on asset usage will lead to subjective and hybrid asset qualifications. The asset value categorization that is suggested in this paper, on the other hand, provides an objective criterion that excludes a well-defined group of assets from the scope of application of EU financial law (i.e. assets that do not entail the liability of an entity and thus only have extrinsic value). Secondly, and more importantly, asset categorizations based upon asset functionalities do not (aim to) identify a common denominator that is inherent to all assets within scope of EU financial legislation. None of the mentioned asset functions (payment, utility, and investment) appears to be a prerequisite for the application of EU financial law. Consequently, it is not immediately clear how the identification of asset functionality could lead to determinative statements about the scope of applications of EU financial law. For instance, not all the assets that fall under the application of EU financial law have an investment functionality.

\subsection{Contents}

The remainder of this paper is structured as follows. First, I propose a conceptual categorization of non-traditional assets based on whether these assets entail the liability of an entity and thus have intrinsic value (no. 2). ${ }^{9}$ The proposed systematization aims to offer a supplementary narrative to the currently prevailing technology- and functionality-focused classifications of non-traditional financial assets. For illustrative purposes, I will apply the value-based asset categorization to the ten non-traditional assets that have the largest market capitalization, as listed on the major data repository for crypto-assets. In the second part of this paper, I aim to demonstrate that the financial instrument notion as employed in EU financial law restricts the application of EU financial law to financial assets that entail the liability of an entity and thus have intrinsic value (no. 3). In line with this thesis, I argue that non-traditional financial assets that only have extrinsic value are not covered by EU financial law and briefly explore the policy implications of this finding. In no. 4, I tentatively explore whether the central thesis of this paper may also be

ance on Cryptoassets' (Consultation Paper CP19/3, January 2019) 8, available via https://www.fca.org.uk/publication/consultation/ cp19-03.pdf; Philipp Maume and Mathias Fromberger, 'Regulation of Initial Coin Offerings: Reconciling U.S. and E.U. Securities Laws' (2019) 19 Chic. J. Int. Law 548, 558 et seq.; Marlinde Nannings, 'Kwalificatie van crypto-assets als effect' (2019) TFR 623, 623 et seq.; Philipp Hacker and Chris Thomale, 'Crypto-Securities Regulation: ICOs, Token Sales and Cryptocurrencies under EU Financial Law' (2018) 15 ECFR 645, 649 et seq.; Alexander Snyers and Karl Pauwels, 'ICOs in Belgium: down the rabbit hole into legal no man's land? Part 1' (2018) 29 ICCLR 483, 488 et seq.

${ }^{8}$ Cf. e.g. Alexander Snyers and Karl Pauwels, 'ICOs in Belgium: down the rabbit hole into legal no man's land? Part 1' (2018) 29 ICCLR 483, 498.

${ }^{9}$ Given the conceptual approach employed in this paper, peculiarities related to national law shall not be covered. of importance to the analysis of non-traditional assets under the different legal conceptualizations of 'money'. Finally, I will conclude in no. 5 .

\section{Recently developed types of financial assets}

\subsection{Novel financial assets that have intrinsic value}

Equities, securitized debt instruments, and derivatives are examples of 'traditional' financial assets. As I aim to demonstrate infra in no. 3, these assets entail the liability of an entity. Equity instruments, for instance, may entail the liability of a company vis-à-vis its shareholder to distribute profits or liquidation proceeds. In recent years, financial markets have witnessed the development of novel types of assets that equally entail the liability of an entity. These novel assets may employ cryptography and/or distributed ledger applications (e.g. blockchain) to facilitate (disintermediated) transferability and security. Nevertheless, this type of novel assets mimics traditional financial assets in that they also derive intrinsic value from the legally enforceable contractual rights that they bestow upon the asset holder. ${ }^{10}$

If the relevant liability is being created for the purpose of financing the issuing entity's business activities, the process through which the novel type of financial asset is conceived is often referred to as an initial coin or token offering (ICO or ITO). ${ }^{11}$ However, it should be stressed that the terminology at hand is not standardized and, hence, different authors and policymakers may attribute different meanings to the referenced terms. Some authors may, for instance, reserve the term 'coin' to refer to assets that have been conceived for payment application purposes. Similarly, some commentators may understand the notion 'token' to also capture assets that do not merely aim to serve as an alternative to traditional fund raising channels. ${ }^{12}$ Most importantly, the terms ICO and ITO do not necessarily imply the establishment of a right for the asset holder vis-à-vis an issuing entity. ${ }^{13}$ Indeed, the concepts are in practice often used to describe the genesis of financial assets that do not entail the liability of an entity (see infra no. 2.3).

Instead of financing (risky) business activities, funds raised through the creation of liability-representing assets may alternatively be invested in low-risk assets. Such usage of the accumulated funds will stabilize the value of the issued assets, regardless of the technologies that may underpin them. By back-

\footnotetext{
10 Typically, a non-traditional asset that entails an entity's liability is created in exchange for a payment by the (prospective) asset holder.

${ }^{11}$ See e.g. Alexander Snyers and Karl Pauwels, 'ICOs in Belgium: down the rabbit hole into legal no man's land? Part 1' (2018) 29 ICCLR 483.

${ }^{12}$ See e.g. Skander Bennis, 'Consumentenbescherming bij blockchain en smart contracts' in Reinhard Steennot and Gert Straetmans (eds), Digitalisering van het recht en consumentenbescherming (Intersentia 2019) 235, 258 (footnote 137).

${ }^{13} \mathrm{Cf}$. the description of the term 'ICO' in Ryan Coffey v. Ripple Labs Inc., et al., 333 F.Supp.3d 952 (Dist. Court, ND California 2018), at 955 .
} 
ing the conceived assets with a stable pool of low yield assets (e.g. bank deposits or liquid short term government bonds ${ }^{14}$ or assuring the stable value of the assets through other means, ${ }^{15}$ the protagonists of this new type of assets aim to offer an alternative to existing currencies. ${ }^{16}$ Since the publication of the Libra White Paper in June 2019, ${ }^{17}$ this type of assets has gravitated towards the center of political and public attention. ${ }^{18}$ These assets are commonly referred to as stablecoins, but also in this context there is no generally accepted definition. Although stablecoins are deliberately designed to maintain their intrinsic value and thus shield the asset holder from risk exposure, ${ }^{19}$ they resemble, for our purposes, assets that are created with a view to funding business activities. That is to say, regardless of the purposes for which funds are collected, the conceived financial assets entail the liability of an entity. For stablecoins, the liability of the issuing entity vis-à-vis the asset holder will typically consist of an obligation to redeem the assets at issuance price. This redemption may either occur through direct interaction between the issuer and the asset holder or, as is the case with Libra, ${ }^{20}$ via a network of dealers, to whom the issuer will in turn be liable for redemption. ${ }^{21}$

${ }^{14}$ See e.g. Christian Catalini, Oliver Gratry, J. Mark Hou, Sunita Parasuraman, Nils Wernerfelt, 'The Libra Reserve' (paper contributed to the Libra Association, last revised 14 August 2019), available via https://ibra.org/en-US/about-currency-reserve/ \#the_reserve.

15 See for other stabilizing mechanisms: G7 Working Group on Stablecoins, 'Investigating the impact of global stablecoins' (G7 Report, October 2019), 24, available via https://www.bis.org/cpmi/ $\mathrm{publ} / \mathrm{d} 187 . \mathrm{pdf}$

${ }^{16}$ See e.g. Libra Association Members, 'An Introduction to Libra' (White Paper, last revised 21 January 2020), available via https:// libra.org/en-us/whitepaper.

17 Libra Association Members, 'An Introduction to Libra' (White Paper, last revised 21 January 2020), available via https://libra.org/ en-us/whitepaper. Since its launch in June 2019 and after severe regulatory pushback, several of the founding members have left the Libra Association. See e.g. Hannah Murphy and Kiran Stacey, 'Penny drops for Facebook's payments partners: Zuckerberg empire hit as regulatory fears on Libra currency trigger exodus' Financial Times (London, 16 October 2019) 17.

${ }^{18}$ See e.g. Denis Beau, 'Stablecoins - a good or a bad solution to improve our payment systems?' (Stablecoin Conference "Which ambitions for Europe?", Paris, 15 January 2020), available via https: //www.bis.org/review/r200115c.htm; G7 Working Group on Stablecoins, 'Investigating the impact of global stablecoins' (G7 Report, October 2019), available via https://www.bis.org/cpmi/publ/d187. pdf; Yves Mersch, 'Money and private currencies - reflections on Libra' (ESCB Legal Conference, Frankfurt am Main, 2 September 2019), available via https://www.bis.org/review/r190902a.htm.

19 Libra Association Members, 'An Introduction to Libra' (White Paper, last revised 21 January 2020), 3, available via https://libra. org/en-us/whitepaper.

${ }^{20}$ Christian Catalini, Oliver Gratry, J. Mark Hou, Sunita Parasuraman, Nils Wernerfelt, 'The Libra Reserve' (paper contributed to the Libra Association, last revised 14 August 2019), 2, available via https://libra.org/en-US/about-currency-reserve/\#the_reserve.

${ }^{21}$ In the case of Libra, the Libra Association is the issuing entity.

\subsection{Novel financial assets that only have extrinsic value}

\subsubsection{Conceptual}

In recent years, financial markets have also witnessed the development of a second novel type of financial assets. Critically different from the assets discussed in no. 2.1, this second type of assets does not entail the liability of any entity. Just like novel asset types that have intrinsic value, these assets may be wired on cryptography and/or distributed ledger applications. However, for the assets discussed in this paragraph, there is no entity that has committed itself to an obligation of any kind vis-à-vis the asset holder. In this respect, these assets resemble assets such as gold and soybeans, which equally do not derive their value from the representation of the liability of an entity. Naturally, the similarity does not go beyond this point, since commodity-like assets have intrinsic value, whereas the assets described in this paragraph do not. Prominent examples of novel financial assets that do not entail the liability of an entity are Bitcoin and Litecoin, but as I aim to demonstrate in no. 2.3, many of the non-traditional assets with large market capitalizations fit within this category.

Much like any other type of financial asset, bitcoins and litecoins are being purchased by investors, who thus attach value to these assets. However, unlike many traditional financial assets, bitcoins and litecoins exclusively derive their value from the interaction between supply and demand. ${ }^{22}$ In this context, market demand expresses the degree to which market participants are willing to transfer e.g. goods, services, or euros in exchange for bitcoins or litecoins (see supra no. 1.1). ${ }^{23}$ If there were no market demand for bitcoins or litecoins, it would be impossible for the coin holder to derive any value from it. ${ }^{24}$

One strand in legal scholarship has suggested that bitcoins may derive their value from the reciprocal obligation for bitcoin-users to accept payment in bitcoins. ${ }^{25}$ In my view, this notion is incorrect. ${ }^{26}$ First, in the EU, no entity is obliged to ac-

${ }^{22}$ Market forces will of course account for factors such as security, transferability, and avoidance of double spending. However, this does not change the fact that any asset value for the asset holder is contingent on outside buying interest in the asset. See also Adrian D. Lee, Mengling Li, and Huanhuan Zheng, 'Bitcoin: Speculative asset or innovative technology?' (2020) 67 J. Int. Financ. Markets Inst. Money, forthcoming.

${ }^{23}$ Vice versa, the willingness of a bitcoin or litecoin holder to transfer his bitcoins or litecoins in exchange for goods, services, euros, dollars, etc. constitutes the market supply for the relevant asset.

${ }^{24}$ The fact that the value of this type of assets is solely determined through the continuous but turbulent interaction between supply and demand may be one of the reasons why these assets have in the past been subject to strong price volatility.

25 See Simon Geiregat, 'Eigendom op bitcoins' (2018) 81 RW 1043, 1047. Cf. Simon Geiregat, 'Cryptocurrencies are (smart) contracts' (2018) 34 CLSR 1144, 1146. See, however, Simon Geiregat, 'Cryptovaluta's in het vermogensrecht: Poging tot gemeenen consumentenrechtelijke kwalificatie' in Mark Delanote and Patrick Waeterinckx (eds), Cryptomunten juridisch ontsloten (Intersentia 2020) 15, 20.

${ }^{26}$ See more in detail: Evariest Callens and Liselotte Van Coillie, 'Cryptomunten in het financieel recht: geen regulering in afwezigheid van enige aanspraak jegens een aanwijsbare 
cept a payment in bitcoins, unless such obligation has been contractually agreed upon (see infra no. 4). In any case, the existence of such obligation cannot be deducted from the mere fact that a person is e.g. holding bitcoins or has used these coins in the past. Secondly, and more importantly, whether entities accept payments in bitcoins or have an obligation to do so (quod non) does not determine the value of these bitcoins. As explained above, the value or purchase power of bitcoins is determined by the degree to which market participants are willing to transfer goods, services, euros, dollars, etc. in exchange for bitcoins. Bitcoin thus derives external asset value from the purchase power that entities are willing to provide in exchange for bitcoins, not from the mere obligation to accept bitcoins.

\subsubsection{Virtual currencies, digital currencies, cryptocurrencies,} and crypto-assets

The novel assets that I have thus far described in no. 2.2 as having only extrinsic value may in more technology-sensitive categorizations e.g. be labeled virtual currencies, digital currencies, cryptocurrencies, or crypto-assets. Once more, however, the terminology at hand is not standardized and, hence, different commentators may understand these terms to mean different things. More importantly, these concepts do not draw a clear division between assets that entail the liability of an entity and assets that only have extrinsic value.

The term 'virtual currency' has been defined by the EU legislator in the anti-money laundering directives as " a digital representation of value that is not issued or guaranteed by a central bank or a public authority, is not necessarily attached to a legally established currency and does not possess a legal status of currency or money, but is accepted by natural or legal persons as a means of exchange and which can be transferred, stored and traded electronically". ${ }^{27}$ This definition reflects quite adequately what international policymakers generally understand to be virtual currencies. The European Central Bank (ECB), for instance, has defined a virtual currency as "a digital representation of value, not issued by a central bank, credit institution or e-money institution, which, in some circumstances, can be used as an alternative to money." 28 Similarly, on the other side of the Atlantic, the US Commodity Futures Trading Commission (CFTC) has defined a virtual currency as "[...] a digital representation of value that may function as a medium of exchange, a unit of account, and/or a store of value [and is] generally run on a decentralized peer-to-peer network." ${ }^{29}$ Comparable descriptions or definitions have been

(rechts)persoon?' in Mark Delanote and Patrick Waeterinckx (eds), Cryptomunten juridisch ontsloten (Intersentia 2020) 39-71.

27 Art. 3(18) Directive (EU) 2015/849 of the European Parliament and of the Council of 20 May 2015 on the prevention of the use of the financial system for the purposes of money laundering or terrorist financing, amending Regulation (EU) No 648/2012 of the European Parliament and of the Council, and repealing Directive 2005/60/EC of the European Parliament and of the Council and Commission Directive 2006/70/EC (text with EEA relevancy), OJ L 141, 5 June 2015, 73.

${ }^{28}$ ECB, 'Virtual currency schemes - a further analysis' (February 2015) 25, available via https://www.ecb.europa.eu/pub/pdf/other/ virtualcurrencyschemesen.pdf.

${ }^{29} \mathrm{~J}$. Christopher Giancarlo, 'Written Statement of J. C. Giancarlo, Chairman of the CFTC, Before the US Senate Com- formulated by the European Securities and Markets Authority (ESMA), the European Banking Authority (EBA), the European Insurance and Occupational Pensions Authority (EIOPA), and the staff of the International Monetary Fund (IMF) ${ }^{30}$ All these policy descriptions of virtual currencies do not define virtual currencies in terms of intrinsic or extrinsic asset value.

Similarly, the term 'digital currency' does not clearly differentiate between assets that derive their intrinsic value from a liability towards the asset holder and assets that only have extrinsic value. According to the Committee on Payments and Market Infrastructures (CPMI) from the Bank for International Settlements (BIS), digital currencies may include money issued by a central bank. ${ }^{31}$ In earlier work, however, the CPMI had stated that "in most cases, [...] digital currencies are assets with their value determined by supply and demand", which have no intrinsic value. ${ }^{32}$

mittee on Banking, Housing, and Urban Affairs' (6 February 2018) 101, 101, available via https://www.govinfo.gov/content/ pkg/CHRG-115shrg28854/pdf/CHRG-115shrg28854.pdf. See also CFTC, 'An Introduction to Virtual Currency', available via https://www.cftc.gov/sites/default/files/idc/groups/public/ @customerprotection/documents/file/oceo_aivc0218.pdf. Cf. CFTC v. McDonnell, 287 F.Supp.3d 213 (Dist. Court, ED New York 2018), at 218.

30 EBA, 'EBA Opinion on virtual currencies' (EBA/Op/2014/08, 4 July 2014) 11 (no. 19), available via https://eba.europa. eu/sites/default/documents/files/documents/10180/657547/ 81409b94-4222-45d7-ba3b-7deb5863ab57/EBA-Op-2014-08\% 200pinion\%20on\%20Virtual\%20Currencies.pdf?retry=1, in which the EBA stated that a virtual currency is a "digital representation of value that is neither issued by a central bank or public authority nor necessarily attached to a [conventional fiat currency], but is used by natural or legal persons as a means of exchange and can be transferred, stored or traded electronically.". Cf. ESMA, EBA, and EIOPA, 'ESMA, EBA and EIOPA warn consumers on the risks of Virtual Currencies', 1, available via https://www.esma.europa.eu/sites/default/files/library/esma50164-1284_joint_esas_warning_on_virtual_currenciesl.pdf: "[virtual currencies are] a digital representation of value that is neither issued nor guaranteed by a central bank or public authority and does not have the legal status of currency or money." See also the description advanced by a group of IMF staff: "[virtual currencies] are digital representations of value, issued by private developers and denominated in their own unit of account" and "[t]he concept of [virtual currencies] covers a wider array of "currencies," ranging from simple IOUs of issuers (such as Internet or mobile coupons and airline miles), [virtual currencies] backed by assets such as gold, and "cryptocurrencies" such as Bitcoin." Dong He et al., 'Virtual Currencies and Beyond: Initial Considerations' (IMF Staff Discussion Note 2016/03, January 2016) 7, available via https://www.imf.org/external/pubs/ft/sdn/2016/sdn1603.pdf.

31 Work from the CPMI shows that central banks have in recent years examined the potential of digital currencies to serve as a new form of digital central bank money. See CPMI, 'Central bank digital currencies' (March 2018), available via https:// www.bis.org/cpmi/publ/d174.pdf. Cf. also Christian Barontini and Henry Holden, 'Proceeding with caution - a survey on central bank digital currency' (BIS Papers no. 101, January 2019), available via https://www.bis.org/publ/bppdf/bispap101.pdf. Critics, on the other hand, claim that the recent attention from central banks for digital currencies has not been genuine. See e.g. Martin Arnold, 'Central bankers' talk of launching digital currencies is all bluff' Financial Times (London, 5 December 2019) 14.

32 CPMI, 'Digital currencies' (November 2015) 4, available via https://www.bis.org/cpmi/publ/d137.pdf. 
Finally, also the term cryptocurrency does not allow to draw a bright line between assets that represent the liability of an entity and assets that only have extrinsic value. There is currently no generally accepted cryptocurrency definition. ${ }^{33} \mathrm{Al}$ though the term is typically associated with assets that are similar to Bitcoin, there are no reasons to assume that cryptographic assets that represent the liability of an entity may not be covered by the term. Indeed, conceptually, a 'currency' may refer to any representation of value that aims to serve a monetary function, ${ }^{34}$ and, hence, the notion is not necessarily limited to assets that only have extrinsic value. Similarly, the concept of crypto-assets is equivocal in this respect, since assets that are underpinned by cryptography may or may not entail the liability of an entity. ${ }^{35}$

Much of the ambiguity surrounding the terminology currently used by the industry can be traced back to the technology- or functionality-sensitive character of the terms that have been employed. The resulting proliferation of definitions, interpretations, and descriptions hampers mutual understanding. ${ }^{36}$ Furthermore, a categorization inspired upon the used technology bears little relation to the technologyinsensitive asset definitions employed in EU financial legislation (see infra no. 3).

\subsection{Asset value categorization of the non-traditional financial assets with the largest market capitalization}

At the time of writing, the market capitalization of Bitcoin equaled $\$ 185.4$ billion. ${ }^{37}$ The other 5108 cryptographic and distributed ledger applications displayed on CoinMarketCap (CMC) - sometimes referred to as 'altcoins' — had a combined market value of $\$ 107.9$ billion, ${ }^{38}$ bringing the total market

\footnotetext{
${ }^{33}$ For an overview of the descriptions formulated by the various relevant international policy makers, see Robby Houben and Alexander Snyers, 'Cryptocurrencies and blockchain: Legal context and implications for financial crime, money laundering and tax evasion' (study requested by the "TAX3" committee of the European Parliament, July 2018) 20-23, available via http://www.europarl.europa.eu/cmsdata/150761/TAX3\% 20Study\%20on\%20cryptocurrencies\%20and\%20blockchain.pdf.

${ }^{34}$ See Lexico by Oxford University Press, https://www.lexico.com/en/ definition/currency, which describes a 'currency' as "[a] system of money in general use in a particular country", or more broadly " $[\mathrm{t}] \mathrm{he}$ fact or quality of being generally accepted or in use".

35 Differently: ECB Crypto-Assets Task Force, "Crypto-Assets: Implications for financial stability, monetary policy, and payments and market infrastructures' (ECB Occasional Paper Series no. 223, May 2019) 3 and 7, available at https://www.ecb.europa.eu/pub/ pdf/scpops/ecb.op223 3ce14e986c.en.pdf.

${ }^{36}$ Cf. ECB Crypto-Assets Task Force, 'Crypto-Assets: Implications for financial stability, monetary policy, and payments and market infrastructures' (ECB Occasional Paper Series no. 223, May 2019) 7 , available at https://www.ecb.europa.eu/pub/pdf/scpops/ ecb.op223 3ce14e986c.en.pdf.

37 https://coinmarketcap.com/currencies/bitcoin/, consulted on 11 February 2020.

${ }^{38} \mathrm{CMC}$ refers to all the applications listed on its website as 'cryptocurrencies'. However, many of the applications show little resemblance to currencies (e.g. Ethereum). If the application operates independently, CMC calls it a 'coin'. If the application cannot function independently (e.g. because it uses a coin's blockchain), CMC refers to it as a 'token'.
}

\begin{tabular}{|l|l|c|r|}
\hline 1 & Bitcoin & BTC & $\$ 185,428,280,114$ \\
\hline 2 & Ether & ETH & $\$ 25,853,176,002$ \\
\hline 3 & Ripple & XRP & $\$ 12,223,851,911$ \\
\hline 4 & Bitcoin Cash & BCH & $\$ 8,416,792,867$ \\
\hline 5 & Bitcoin SV & BSV & $\$ 6,623,957,582$ \\
\hline 6 & EOS & EOS & $\$ 4,991,170,602$ \\
\hline 7 & Litecoin & LTC & $\$ 4,887,835,871$ \\
\hline 8 & Tether & USDT & $\$ 4,635,042,097$ \\
\hline 9 & Binance Coin & BNB & $\$ 3,940,439,374$ \\
\hline 10 & Tez & XTZ & $\$ 2,000,748,229$ \\
\hline
\end{tabular}

Fig. 2 - The ten assets listed on CMC with the largest market capitalization (11 February 2020). ${ }^{168}$

value of all reported applications to $\$ 293.3$ billion. ${ }^{39}$ For comparison, this combined market capitalization roughly equals the market capitalization of a single large multinational company (e.g. the market cap of Taiwan Semiconductor Manufacturing Co. Ltd. is $\$ 304.3$ billion $)^{40}$ or a fraction of the market capitalization of the US company with the largest market capitalization (the market cap of Apple Inc. is $\$ 1398$ billion). ${ }^{41}$

\subsubsection{Non-traditional assets that only have extrinsic value} The ten assets listed on CMC that have the largest market capitalization contain a subset of assets that resemble Bitcoin in that they only have extrinsic value (Ether, Ripple, Bitcoin Cash, Bitcoin SV, EOS, Litecoin, Binance Coin, and Tez). Some of these assets strongly resemble Bitcoin in their functionalities (Bitcoin Cash, Bitcoin SV, and Litecoin) and will therefore not be discussed in detail in this paper. ${ }^{42}$ In the following paragraphs, I discuss why Ether, Ripple, EOS, Binance Coin, and Tez only have extrinsic value.

Binance coin: Binance Coin is an asset that has been issued by one of the largest crypto-exchanges in the world (i.e. the Binance Exchange) and runs on the Ethereum blockchain. ${ }^{43}$ The Binance Whitepaper stipulates that the Binance Exchange accepts binance coins as payment for any fees related to the

\footnotetext{
39 Ibid. Although alternative data repositories exist (e.g. https: //onchainfx.com/), CMC is by far the most dominant provider of market data in the crypto sphere. It is my understanding that CMC provides the most comprehensive overview of the market. For an overview of non-traditional financial assets that have failed, see https://deadcoins.com/.

40 See https://ycharts.com/companies/TSM, consulted on 11 February 2020.

41 https://ycharts.com/companies/AAPL/market_cap, consulted on 11 February 2020.

42 Bitcoin Cash and Bitcoin SV have directly originated from Bitcoin and aim to offer more scalable alternatives to Bitcoin. Bitcoin was split ('forked') into Bitcoin and Bitcoin Cash and Bitcoin Cash was in turn split into Bitcoin Cash and Bitcoin SV. Litecoin also strongly resembles Bitcoin's functionalities, despite the many differences in the technologies underpinning both assets (e.g. the algorithms in the mining process). See https://litecoin.org/.

${ }^{43}$ See Binance Exchange, 'Binance Whitepaper v.1.2', available via https://www.binance.com/resources/ico/ Binance_WhitePaper_en.pdf.
} 
services provided by the platform. ${ }^{44}$ Nevertheless, the mere fact that an entity has contractually agreed to accept a certain type of asset (e.g. binance coins, gold, or soybeans) in exchange for a predefined set of services does not mean that the designated asset entails a liability or has intrinsic value. Critically different from assets that entail the liability of an entity, any value that a coin holder may derive from binance coins presupposes the existence of a liability vis-à-vis the Binance Exchange. ${ }^{45}$ In other words, the Binance Exchange is obliged to accept binance coins as a payment if services are delivered, but no obligation to deliver services arises from a binance coin. Hence, the liability to accept a payment in binance coins is exogenous to the coin and, consequently, binance coins as such do not have intrinsic value. Instead, the contractual commitment to accept binance coins as a means of payment is merely an expression of the market demand for binance coins (i.e. the degree to which market participants are willing to exchange services, goods, legal tender, etc. for binance coins). This market demand contributes to the extrinsic asset value of binance coins.

Ether, Ripple, and Tez: Ethereum is a blockchain-based platform that offers the code and software for the design of a wide variety of decentralized applications, which can all be built upon the Ethereum blockchain. ${ }^{46}$ Ether, on the other hand, is the asset that the developers of applications can (and must) use to pay the fees charged by miners for the processing of Ethereum transactions (e.g. for the execution of smart contracts). ${ }^{47}$ As with binance coins, ethers do not entail the liability of an entity vis-à-vis the asset holder. ${ }^{48}$ Naturally, the fact that ethers may be exchanged for e.g. services in relation to smart contracts gives ethers a substantial external value.

Ripple Labs Inc. is a company that has developed a distributed ledger that aims to facilitate rapid and cheap crossborder payments with real-time settlement between financial institutions. ${ }^{49}$ Ripple (XRP) is the asset (sometimes called the 'central currency') that entities can use to execute the cross-

\footnotetext{
44 Binance Exchange, 'Binance Whitepaper v.1.2', available via https://www.binance.com/resources/ico/Binance_WhitePaper_ en.pdf.

45 Indeed, the right to pay in binance coins (e.g. for a delivered service) is conceptually different from the right to receive a service from the Binance Exchange.

${ }^{46}$ Vitalik Buterin, 'A Next Generation Smart Contract \& Decentralized Application Platform' (Ethereum White Paper), available via https://pdfs.semanticscholar.org/0dbb/ 8a54ca5066b82fa086bbf5db4c54b947719a.pdf?_ga=2.175027233. 2030949799.1581617651-192866814.1581617651.

47 Vitalik Buterin, 'A Next Generation Smart Contract \& Decentralized Application Platform' (Ethereum White Paper) 13 and 30, available via https://pdfs.semanticscholar.org/0dbb/ 8a54ca5066b82fa086bbf5db4c54b947719a.pdf?_ga=2.175027233. 2030949799.1581617651-192866814.1581617651.

48 In October 2019, CFTC Chairman Heath P. Tarbert stated publicly that the CFTC considers Ether to qualify as a commodity under US law. See CFTC, 'Chairman Tarbert Comments on Cryptocurrency Regulation at Yahoo! Finance All Markets Summit' (Press Release, 10 October 2019), available via https://www.cftc. gov/PressRoom/PressReleases/8051-19.

49 https://ripple.com/.
}

border payments via the distributed ledger. ${ }^{50}$ It is my understanding that Ripple does not entail the liability of Ripple Labs Inc. or any other entity vis-à-vis the asset holder. In the US, class actions have been brought against Ripple Labs Inc. for alleged violations of US securities laws. ${ }^{51}$ Thus far, there is no decision that has determined that Ripple constitutes a security within the meaning of the US Securities Act of $1933 .{ }^{52}$ In any case, the interpretation of the US securities notion does not easily translate to the European context (see infra no. 3.2.3).

Tezos is a self-amending decentralized ledger that, similarly to Ethereum, has been developed to allow entities to construe smart contracts. ${ }^{53} \mathrm{Tez}$ is the asset that allows entities to pay for services related to the distributed ledger. ${ }^{54}$ To my understanding and similar to the other assets discussed in this section, Tez does equally not represent the liability of an entity.

EOS: the Cayman Islands-incorporated company named 'block.one' has developed software ('EOSIO') that can function as an operating system for one or more EOSIO-based blockchains. ${ }^{55}$ Comparably to other decentralized ledgers discussed above, EOSIO-based blockchains are decentralized systems that aim to facilitate the construal of decentralized applications. ${ }^{56}$ Fundamentally different from the blockchains discussed above (e.g. Ethereum), cryptographic tokens issued in relation to EOSIO-based blockchains are not needed to pay transaction fees. Instead, the cryptographic tokens related to an EOSIO-based blockchain express the degree to which the holder can use the resources of the blockchain (i.e. essentially bandwidth, storage, and computational power). ${ }^{57}$ In other

\footnotetext{
50 https://ripple.com/. Unlike other non-traditional financial assets, Ripple is not mined. All 100 billion XRP have existed since the development of Ripple in 2013. Ripple Labs Inc. and the developers of Ripple still hold large portions of these coins and periodically sell parts of their reserves to other entities. See Ryan Coffey v. Ripple Labs Inc., et al., 333 F.Supp.3d 952 (Dist. Court, ND California 2018), at 954 and 955.

51 See Vladi Zakinov, et al., v. Ripple Labs, Inc., et al., 369 F.Supp.3d 950 (Dist. Court, ND California 2019); Avner Greenwald v. Ripple Labs, Inc., et al., Case no. 18-cv-04790-PJH (Dist. Court, ND California 2018); Ryan Coffey v. Ripple Labs Inc., et al., 333 F.Supp.3d 952 (Dist. Court, ND California 2018). See also https://www.courtlistener.com/recap/gov.uscourts.cand. 334410/gov.uscourts.cand.334410.70.0.pdf The District Court has not answered the question whether Ripple constitutes a security. 52 Pub. L. No. 73-291, 48 Stat. 74 (1933).

53 L.M Goodman, 'Tezos - a self-amending crypto-ledger' (White paper, 2 September 2014), available via https://tezos.com/static/ white_paper-2dc8c02267a8fb86bd67a108199441bf.pdf.

54 L.M Goodman, 'Tezos - a self-amending crypto-ledger' (White paper, 2 September 2014), available via https://tezos.com/static/ white_paper-2dc8c02267a8fb86bd67a108199441bf.pdf.

55 SEC, 'Order Instituting Cease-and-Desist Proceedings in the Matter of Block.one' (Administrative Proceeding File no. 3-19568, 30 September 2019), at 2.

56 block.one, 'EOS.IO Technical White Paper v2' (16 March 2018), available via https://github.com/EOSIO/Documentation/ blob/master/TechnicalWhitePaper.md; Ian Grigg, 'EOS - An Introduction' (EOS White Paper, 5 July 2017), available via https: //whitepaperdatabase.com/eos-whitepaper/.

57 block.one, 'EOS.IO Technical White Paper v2' (16 March 2018), available via https://github.com/EOSIO/Documentation/ blob/master/TechnicalWhitePaper.md.
} 
words, the holder of ten percent of the tokens may use (or rent-out) ten percent of the blockchain's resources. ${ }^{58}$ This system is known in the industry as the 'ownership model'. ${ }^{59}$ The resources of the blockchain are provided by so-called 'block producers' (BPs). These are entities that are being selected through a continuous election process in which the entities holding the cryptographic tokens linked to the blockchain cast votes. Anyone can solicit votes to be elected as a BP and the BPs are rewarded through the creation of additional tokens (i.e. an inflation-like reward system).

According to the US Securities and Exchange Commission (SEC), 'block.one' has sold 900 million of the 1 billion created 'ERC-20 Tokens' (i.e. tokens distributed via the relevant Ethereum smart contract or 'EOS Tokens'), 60 retaining 100 million 'founder tokens'. The token purchasers paid $\$ 4$ billion to block.one for the acquisition of these digital assets. ${ }^{61}$ A substantial amount, considering that the relevant 'token purchase agreement' stipulated in no uncertain terms that none of the assets would grant the asset holder any rights, uses, purposes, functionalities etc. ${ }^{62}$ The ERC-20 Tokens were not even tokens that could potentially be used on any future EOSIO-based blockchain. ${ }^{63}$ Instead, the publicly available and freely adaptable standard version of the EOSIO-software merely determined that the holders of ERC-20 Tokens were to receive other cryptocraphic tokens for use on EOSIO-based blockchains in proportion to the relative amount of ERC-20 Tokens that they held. However, the agreement also determined that block.one would not develop any EOSIO-based blockchain and that any EOSIO-based blockchain would thus have to be developed by a third party. ${ }^{64}$ Even if a third party were to de-

58 block.one, 'EOS.IO Technical White Paper v2' (16 March 2018), available via https://github.com/EOSIO/Documentation/ blob/master/TechnicalWhitePaper.md.

${ }^{59}$ Cf. e.g. https://blockgeeks.com/guides/eos-blockchain/.

60 SEC, 'Order Instituting Cease-and-Desist Proceedings in the Matter of Block.one' (Administrative Proceeding File no. 3-19568, 30 September 2019), at 2; SEC, 'SEC Orders Blockchain Company to Pay \$24 Million Penalty for Unregistered ICO' (SEC Press Release, 30 September 2019), available via https:/www.sec.gov/ news/press-release/2019-202.

${ }^{61}$ See e.g. Kate Rooney, 'A blockchain start-up just raised \$4 billion without a live product' CNBC (31 May 2018), available via https://www.cnbc.com/2018/05/31/ a-blockchain-start-up-just-raised-4-billion-without-a-live-product html. Payment occurred in Ether. At the time of the acquisition, the market value of the ethers used to finance the purchase of the ERC-20 Tokens was equivalent to $\$ 4$ billion.

62 EOS Token Purchase Agreement (Last updated: 4 September 2017), available via https://d340lr3764rrcr.cloudfront. net/purchase_agreement/block.one+-+EOS+Token+Purchase+ Agreement+-+September+4\%2C+2017.pdf.

63 EOS Token Purchase Agreement (Last updated: 4 September 2017), available via https://d340lr3764rrcr.cloudfront. net/purchase_agreement/block.one+-+EOS+Token+Purchase+ Agreement+-+September+4\%2C+2017.pdf. Cf. SEC, 'Order Instituting Cease-and-Desist Proceedings in the Matter of Block.one' (Administrative Proceeding File no. 3-19568, 30 September 2019), at 3 (no. 7).

${ }^{64}$ EOS Token Purchase Agreement (Last updated: 4 September 2017), available via https://d340lr3764rrcr.cloudfront. net/purchase_agreement/block.one+-+EOS+Token+Purchase+ Agreement+-+September+4\%2C+2017.pdf. cide to develop an EOSIO-based blockchain, there exited no guarantee that developers would distribute the tokens for the EOSIO-based blockchain in proportion to the holdings of the relevant ERC-20 Tokens. Although the first developed EOSIObased blockchain (the 'EOS Blockchain') did indeed distribute the EOSIO-blockchain tokens (called 'EOS' or 'EOS Tokens') according to the volume of the relevant ERC-20 Tokens that market participants had acquired, more recent initiatives have deviated from, or intend to deviate from, the division of powers determined by the ERC-20 Tokens distribution. ${ }^{65}$

The SEC has argued that the ERC-20 Tokens qualify as securities under US law and, hence, that block.one has violated its obligation under US law to obtain registration with the SEC for selling these tokens. However, the SEC has agreed to settle with block.one in exchange for the payment of a civil money penalty of $\$ 24$ million. ${ }^{66}$ In any case, the ERC-20 tokens that were sold by block.one do not entail the liability of block.one or any other entity. To the extent that a blockchain uses (an unamended version of) the EOSIO-software (e.g. the EOS blockchain), the software will only allow the holder of the relevant cryptographic tokens to use his or her proportional part of the blockchain resources. ${ }^{67}$ To my understanding, the holder of a cryptographic token linked to an EOSIObased blockchain (e.g. 'EOS') has no right vis-à-vis a BP or a central entity. BPs may decide to stop providing services at any time. Naturally, by establishing a right to use the resources of the blockchain (if any), cryptographic tokens linked to EOSIObased blockchains may obtain a significant extrinsic value.

\subsubsection{Non-traditional assets that have intrinsic value}

In my view, only one asset within the CMC's top ten of nontraditional assets with the largest market capitalization entials the liability of an entity: Tether. So-called 'tethers' are cryptographic tokens that are "backed in a one-to-one ratio [...] by the corresponding fiat currency unit held in deposit by Hong Kong based Tether Limited." ${ }^{68}$ Verified entities holding tethers may redeem their coins with a central custodian (i.e. Tether Limited) in exchange for bitcoins or the fiat currency underlying the tethers (i.e. US dollars, euros, or offshore Chinese yuan). ${ }^{69} \mathrm{~A}$ tether thus represents the liability of Tether Limited vis-à-vis the tether holder to redeem the coin for the reserve assets held

65 See e.g. Brady Dale, 'Everyone's Worst Fears About EOS Are Proving True' (19 September 2019), available via https://www.coindesk. com/everyones-worst-fears-about-eos-are-proving-true.

66 SEC, 'Order Instituting Cease-and-Desist Proceedings in the Matter of Block.one' (Administrative Proceeding File no. 3-19568, 30 September 2019), at 6; SEC, 'SEC Orders Blockchain Company to Pay \$24 Million Penalty for Unregistered ICO' (SEC Press Release, 30 September 2019), available via https://www.sec.gov/ news/press-release/2019-202.

67 block.one, 'EOS.IO Technical White Paper v2' (16 March 2018), available via https://github.com/EOSIO/Documentation/ blob/master/TechnicalWhitePaper.md.

68 Tether, 'Tether: Fiat currencies on the Bitcoin blockchain' (White Paper, June 2016), at 4, available via https://tether.to/ wp-content/uploads/2016/06/TetherWhitePaper.pdf.

69 Tether, 'Tether: Fiat currencies on the Bitcoin blockchain' (White Paper, June 2016), at 4, available via https://tether.to/ wp-content/uploads/2016/06/TetherWhitePaper.pdf; Tether, 'Tether Limited Terms of Service' (last updated 26 February 2019), at no. 3, available via https://tether.to/legal/. 
by Tether Limited. ${ }^{70}$ Although the protagonists of Tether aim to provide users with the functionalities of so-called stablecoins (see supra no. 2.1), inter alia by guaranteeing that the balance of reserve fiat currencies will remain equal to (or greater than) the number of tethers in circulation, ${ }^{71}$ it appears that Tether Limited might have defrauded its investors and that Tether is (no longer) backed by sufficient reserves to allow full redemption for all investors. ${ }^{72}$ Naturally, this does not change the fact that tethers entail the liability of Tether Limited.

\section{Assets that only have extrinsic value are not financial instruments}

\subsection{EU financial law governs assets that entail liabilities}

EU financial legislation employs multiple anchor points to determine its scope of application. In many legislative acts, a pivotal determinant pertains to the properties of the financial assets that are e.g. being offered, traded, advised, cleared, or settled. For instance, the prospectus obligation in the Prospectus Regulation only applies to certain securities, ${ }^{73}$ the clearing obligation in the European Markets Infrastructure Regulation (EMIR) only applies to certain classes of OTC derivatives, ${ }^{74}$ and all rules in the Market Abuse Regulation (MAR) only apply to certain financial instruments. ${ }^{75}$ These examples merely provide a flavor of the wide variety of financial assets that may

70 Tether, 'Tether Limited Terms of Service' (last updated 26 February 2019), at no. 3, available via https://tether.to/legal/.

71 Tether, 'Tether: Fiat currencies on the Bitcoin blockchain' (White Paper, June 2016), at 4, available via https://tether.to/ wp-content/uploads/2016/06/TetherWhitePaper.pdf.

72 In the Matter of the Inquiry by Letitia James, Attorney General of the State of New York v. iFinex Inc. et al., Docket no. 450545/2019 (Supreme Court, New York County), all 126 documents in relation to the case are available via https://iapps.courts.state.ny.us/nyscef/DocumentList? docketId=npvulMdOYzFDYIAomW_PLUS_elw=\&\&display= all\&; courtType=New\%20York\%20County\%20Supreme\%

20Court\&resultsPageNum=1; New York State Attorney General, 'Attorney General James Announces Court Order Against "Crypto" Currency Company Under Investigation For Fraud' (Press Release, 25 April 2019), available via https://ag.ny.gov/press-release/2019/ attorney-general-james-announces-court-order-against-cryptocurrency-company; Michael Patterson and Eric Lam, 'Cryptocurrencies Lose $\$ 10$ Billion on Tether Cover-Up Allegations' (Bloomberg, 26 April 2019), available via https://www. bloomberg.com/news/articles/2019-04-26/cryptocurrencies-lose10-billion-on-tether-cover-up-allegations.

73 Art. 1(1) Regulation (EU) 2017/1129 of the European Parliament and of the Council of 14 June 2017 on the prospectus to be published when securities are offered to the public or admitted to trading on a regulated market, and repealing Directive 2003/71/EC (text with EEA relevancy), OJ L 168, 30 June 2017, p. 12 (Prospectus Regulation).

${ }^{74}$ Art. 4(1) Regulation (EU) No 648/2012 of the European Parliament and of the Council of 4 July 2012 on OTC derivatives, central counterparties and trade repositories (text with EEA relevancy), OJ L 20127 July 2012, p. 1 (EMIR).

75 Art. 2(1) Regulation (EU) No 596/2014 of the European Parliament and of the Council of 16 April 2014 on market abuse (market abuse regulation) and repealing Directive 2003/6/EC of the European Parliament and of the Council and Commission Direc- be used by the legislator to determine the scope of application of different EU directives and regulations in the field of financial law. Furthermore, additional requirements will typically have to be fulfilled in order for a certain financial asset to be covered by the scope of a legislative act. With regard to the prospectus obligation, for instance, it is only the subset of securities that are offered to the public or admitted to trading on a regulated market situated or operating within a EU member state for which a prospectus must be published. ${ }^{76}$

The central thesis of this paper maintains that the large majority, if not all, financial assets subject to EU financial legislation have at least one characteristic in common: they entail an entity's liability. A comprehensive verification of this proposition would require the assessment of all rules prescribed in EU financial legislation. In light of the impracticality of such study, I will only be able to provide narrative evidence, which I will construe around the financial instrument notion as defined in the second markets in financial instruments directive (MiFID II). ${ }^{77}$ To my understanding, MiFID's financial instrument notion is one of the broadest EU conceptions of financial assets. This financial instrument notion has also been referenced by many other EU legislative acts in the sphere of financial markets. Furthermore, for the purposes of this paper, non-MiFID definitions of financial instruments strongly resemble the MifID notion.

\subsection{Financial instruments}

\subsubsection{Relevancy of the concept}

Financial instruments as defined in MiFID II: MiFID II contains numerous rules that attach their scope of application to the 'financial instrument' notion. For example, the conduct of business rules that investment firms have to observe in dealings with their clients only relate to financial instruments (arts. 2430 MiFID II).$^{78}$ Other pieces of EU financial legislation reference the financial instrument concept as defined in MiFID II when defining the scope of certain rules. This is, for instance, the case in the Markets in Financial Instruments Regulation (Mi-

tives 2003/124/EC, 2003/125/EC and 2004/72/EC (text with EEA relevancy), OJ L 173, 12 June 2014, p. 1 (MAR).

76 Art. 1(1) Prospectus Regulation.

77 'Financial instrument' is defined in art. 4(1)(15) juncto Annex I, Part C, to Directive 2014/65/EU of the European Parliament and of the Council of 15 May 2014 on markets in financial instruments and amending Directive 2002/92/EC and Directive 2011/61/EU (recast) (text with EEA relevancy), OJ L 17312 June 2014, p. 349 (MiFID II). MiFID II is the successor to Directive 2004/39/EC of the European Parliament and of the Council of 21 April 2004 on markets in financial instruments amending Council Directives 85/611/EEC and 93/6/EEC and Directive 2000/12/EC of the European Parliament and of the Council and repealing Council Directive 93/22/EEC, OJ L 145, 30 April 2004, p. 1 (MiFID I). I use 'MiFID' to refer to MiFID I and II together. MiFID I contained a similar definition of the financial instrument notion (see art. 4(1)(17) juncto Annex I, Part C MiFID I).

78 The relevant provisions either directly limit their scope of application to financial instruments or refer to notions that have been defined in relation to financial instruments (e.g. 'investment advice' (art. 4(1)(4) MiFID II) and 'investment services and activities' (art. 4(1)(2) MiFID II)). 
FIR), ${ }^{79}$ which, among other things, imposes a reporting obligation on investment firms for transactions in financial instruments (art. 26 MiFIR). Similarly, all rules embedded in the MAR only apply to (certain) financial instruments, as defined in MiFID II. ${ }^{80,81}$

Other EU financial legislation refers to specific types of the financial instruments defined in MiFID II. For instance, the Prospectus Regulation only requires the publication of a prospectus for securities that are offered to the public or admitted to trading on a regulated market situated or operating within the EU. ${ }^{82}$ The term securities, as employed in the Prospectus Regulation, refers to the term 'transferable securities' as defined in MiFID II (art. 2(a) Prospectus Regulation). ${ }^{83}$ As will be described in more detail infra (no. 3.2.3), transferable securities are one of the subtypes of financial instruments.

MifID II provides an exhaustive list of instruments that qualify as financial instruments within the meaning of the Directive. ${ }^{84}$ The following elements have been designated as financial instruments: (i) transferable securities; (ii) money market instruments; (iii) units in collective investment undertakings; (iv) certain derivatives $;^{85}$ and (v) certain emission allowances. ${ }^{86}$ The formally exhaustive nature of the list does

79 See art. 2(1)(9) Regulation (EU) No 600/2014 of the European Parliament and of the Council of 15 May 2014 on markets in financial instruments and amending Regulation (EU) No 648/2012 (text with EEA relevancy), OJ L 173, 12 June 2014, p. 84 (MiFIR), which refers to the financial instrument notion as defined in MiFID II.

80 See supra no. 3.1. See also art. 3(1) MAR, which refers to MiFID II for the interpretation of the financial instruments notion.

${ }^{81}$ The alternative investment fund managers directive (AIFMD) also defines 'financial instrument' by reference to MiFID II. See art. 4(1)(n) Directive 2011/61/EU of the European Parliament and of the Council of 8 June 2011 on Alternative Investment Fund Managers and amending Directives 2003/41/EC and 2009/65/EC and Regulations (EC) No 1060/2009 and (EU) No 1095/2010 (text with EEA relevancy), OJ L 174, 1 July 2011, p. 1 (AIFMD). However, the financial instrument notion is not used to determine the scope of AIFMD rules.

${ }^{82}$ Art. 1(1) Prospectus Regulation. The former Prospectus Directive also imposed this obligation. See art. 1(1) Directive 2003/71/EC of the European Parliament and of the Council of 4 November 2003 on the prospectus to be published when securities are offered to the public or admitted to trading and amending Directive 2001/34/EC (text with EEA relevancy), OJ L 34531 December 2003, p. 64 (Prospectus Directive). On 21 July 2019, the majority of the Prospectus Directive's provisions were replaced by the Prospectus Regulation (see art. 46 juncto art. 49 Prospectus Regulation).

${ }^{83}$ More specifically, the definition of 'securities' in the Prospectus Regulation refers to the MiFID II 'transferable securities' notion and excludes money market instruments (as defined in MiFID II) with a maturity of less than twelve months. The latter component of the definition is somewhat odd, as under MiFID II money market instruments do by definition not qualify as transferable securities because they are traded on the money market and not on the capital market.

${ }^{84}$ See Annex I, Part C, MiFID II.

${ }^{85}$ MiFID II defines 'derivatives' in a peculiar way. Art. 4(1)(49) MiFID II defines derivatives by reference to art. 2(1)(29) MiFIR. However, art. 2(1)(29) MiFIR in turn refers back to MiFID II. More precisely, MiFIR states that derivatives are the financial instruments that are (i) defined in art. 4(1)(44)(c) MiFID II; and (ii) listed in Annex I, Section C, (4) to (10) MiFID II.

${ }^{86}$ More specifically, Annex I, Part C, MiFID II contains the following list of financial instruments: "(1) Transferable securities; (2) not mean that the financial instrument notion has been de facto exhaustively defined. Some of the listed financial instruments are themselves defined open-ended, which means that the financial instrument concept is not as exhaustively defined as one may initially suspect.

Financial instruments as defined in other EU legislation: Besides the EU legislative acts that literally reference MiFID II for the interpretation of the financial instruments notion, there exists also legislation that establishes an independent definition of financial instruments. For instance, the Financial Collateral Directive (FCD), which was adopted in 2002 and thus preceded the adoption of MiFID I, provides a standalone definition of financial instruments. ${ }^{87}$ This definition strongly resembles the MiFID II definition in that it essentially coversin MiFID-terminology-transferable securities, units in collective investment undertakings, and money market instruments. More recent additions to the MiFID notion of financial instruments (e.g. emission allowances) ${ }^{88}$ are not covered by the FCD-definition. In any case, the arguments that are developed below in the context of the MiFID II financial instrument definition equally apply to the definition in the FCD.

Money-market instruments; (3) Units in collective investment undertakings; (4) Options, futures, swaps, forward rate agreements and any other derivative contracts relating to securities, currencies, interest rates or yields, emission allowances or other derivatives instruments, financial indices or financial measures which may be settled physically or in cash; (5) Options, futures, swaps, forwards and any other derivative contracts relating to commodities that must be settled in cash or may be settled in cash at the option of one of the parties other than by reason of default or other termination event; (6) Options, futures, swaps, and any other derivative contract relating to commodities that can be physically settled provided that they are traded on a regulated market, a MTF, or an OTF, except for wholesale energy products traded on an OTF that must be physically settled; (7) Options, futures, swaps, forwards and any other derivative contracts relating to commodities, that can be physically settled not otherwise mentioned in point 6 of this Section and not being for commercial purposes, which have the characteristics of other derivative financial instruments; (8) Derivative instruments for the transfer of credit risk; (9) Financial contracts for differences; (10) Options, futures, swaps, forward rate agreements and any other derivative contracts relating to climatic variables, freight rates or inflation rates or other official economic statistics that must be settled in cash or may be settled in cash at the option of one of the parties other than by reason of default or other termination event, as well as any other derivative contracts relating to assets, rights, obligations, indices and measures not otherwise mentioned in this Section, which have the characteristics of other derivative financial instruments, having regard to whether, inter alia, they are traded on a regulated market, OTF, or an MTF; (11) Emission allowances consisting of any units recognised for compliance with the requirements of Directive 2003/87/EC (Emissions Trading Scheme)."

87 Art. 2(1)(e) Directive 2002/47/EC of the European Parliament and of the Council of 6 June 2002 on financial collateral arrangements, OJ L 168, 27 June 2002, p. 43 (FCD).

88 Emission allowances were only included in the list of financial instruments after the adoption of MiFID II. 


\subsubsection{Instruments}

Prior to examining the different types of financial instruments, it may be worthwhile to first consider the meaning of the umbrella term financial instruments. In common parlance, an instrument refers to a 'tool', a 'means of pursuing an aim', or a 'legal document'. ${ }^{89}$ When used in relation to financial assets, I am tempted to think that the word refers to the means that make an investment possible. To my understanding, means of investment have to be distinguished from the actual object of investment. In other words, gold, real estate, and soybeans may serve as investments, but they do not qualify as (investment) instruments. On the other hand, shares of a gold exchange traded fund (ETF), bonds issued by a real estate company, and futures on soybeans may all be called investment instruments. These instruments give expression to a specific and predefined contractual liability of an entity visà-vis the instrument holder.

\subsubsection{Transferable securities}

MiFID II: Transferable securities form a major subtype of MiFID's financial instruments notion. MiFID II defines 'transferable securities' as "those classes of securities which are negotiable on the capital market, with the exception of instruments of payment". ${ }^{90}$ This means that in order to qualify as a transferable security, an asset must meet the following conditions:

1) the asset has to be a security;

2) the security has to be negotiable;

3) the negotiation must occur on the capital market;

4) the security negotiable on the capital market must not be an instrument of payment.

The definition continues by illustratively listing,, ${ }^{91}$ among other things, ${ }^{92}$ shares, bonds, and-maybe surprisingly ${ }^{93}-$

\footnotetext{
${ }^{89}$ Lexico by Oxford University Press, https://www.lexico.com/ definition/instrument.

90 Art. 4(1)(44) MiFID II.

91 The illustrative character of the list follows from the usage of the words "such as".

92 The complete list of examples includes the following assets: "shares in companies and other securities equivalent to shares in companies, partnerships or other entities, and depositary receipts in respect of shares; (b) bonds or other forms of securitised debt, including depositary receipts in respect of such securities; (c) any other securities giving the right to acquire or sell any such transferable securities or giving rise to a cash settlement determined by reference to transferable securities, currencies, interest rates or yields, commodities or other indices or measures". See art. 4(1)(44) MiFID II.

93 The inclusion of derivatives within the concept of transferable securities implies that derivatives are securities. The notion that derivatives are securities is opposed to a more conservative understanding of the securities concept. Such restrictive interpretation only includes equity and securitized debt instruments (i.e. in essence (instruments similar to) shares and bonds) in the securities concept. This is the meaning typically attributed to 'securities' in financial markets jargon.
}

derivatives ${ }^{94}$ as transferable securities. ${ }^{95}$ Given its exemplary nature, this list does not, in my view, have a restrictive effect on the instruments that could potentially be brought under the transferable security notion. ${ }^{96}$ The criteria referenced in the definition also mean that the mentioned illustrations do not unconditionally qualify as transferable securities. For instance, shares that are not negotiable on the capital market will not qualify as transferable securities. ${ }^{97}$

As can be seen from the first criterion, the transferable securities definition is largely circular. Although the definition sheds some light on the interpretation of the adjective 'transferable', the meaning of the notion 'security' remains undefined. In other EU legislative acts, the notion 'security' equally remains undefined. ${ }^{98}$ Nevertheless, the illustrations of transferable securities that are mentioned in the MiFID II definition are assets that entail a certain liability of an entity vis-à-vis the asset holder. ${ }^{99}$ For example, shares entail a company's liability vis-à-vis a shareholder, bonds entail an issuer's liability

${ }^{94}$ See the description under (c) in the illustrations listed in art. 4(1)(44) MiFID II (supra footnote 92): “(c) any other securities giving the right to acquire or sell any such transferable securities or giving rise to a cash settlement determined by reference to transferable securities, currencies, interest rates or yields, commodities or other indices or measures [own emphasis]." The fact that the notion transferable securities captures derivatives has been confirmed by the European Commission: European Commission, 'Q\&As on MiFID', 39, https://ec.europa.eu/info/law/markets-financial-instrumentsmifid-directive-2004-39-ec/implementation/guidanceimplementation-and-interpretation-law_en: "[forwards on securities] may be either transferable securities according to Article 4(1)(18) [MiFID I] or other derivative contracts according to Section C(4) of Annex I [MifID I]". More fundamentally, the fact that derivatives can qualify as derivatives also follows from MiFID's definition of derivatives (see supra footnote 85), which references a part of the MifID-definition of transferable securities. Cf. also Philipp Maume and Mathias Fromberger, 'Regulation of Initial Coin Offerings: Reconciling U.S. and E.U. Securities Laws' (2019) 19 Chic. J. Int. Law 548, 583-584 ("a forward contract on oranges would also be a transferable security"); Philipp Hacker and Chris Thomale, 'Crypto-Securities Regulation: ICOs, Token Sales and Cryptocurrencies under EU Financial Law' (2018) 15 ECFR 645, 670 ("[a] typical example of the last category are stock options").

95 Art. 4(1)(44) MiFID II.

${ }^{96} \mathrm{Cf}$. European Commission, 'Q\&As on MiFID', 22, https://ec.europa.eu/info/law/ markets-financial-instruments-mifid-directive-2004-39-ec/

implementation/guidance-implementation-and-interpretation-law_ en. Differently: Philipp Hacker and Chris Thomale, 'CryptoSecurities Regulation: ICOs, Token Sales and Cryptocurrencies under EU Financial Law' (2018) 15 ECFR 645, 670.

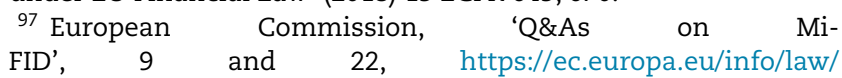
markets-financial-instruments-mifid-directive-2004-39-ec/ implementation/guidance-implementation-and-interpretation-law_ en.

98 To the best of my knowledge, there is also no decision from the European Court of Justice (ECJ) that defines the security notion. Cf. Philipp Maume and Mathias Fromberger, 'Regulation of Initial Coin Offerings: Reconciling U.S. and E.U. Securities Laws' (2019) 19 Chic. J. Int. Law 548, 573-574; Marlinde Nannings, 'Kwalificatie van crypto-assets als effect' (2019) TFR 623, 625.

99 See supra footnote 92 for the complete list of mentioned examples. 
vis-à-vis a bondholder, and derivatives entail the contingent liabilities of the counterparties to the contract (or the liability of the party that is out of the money vis-à-vis the party that is in the money, if changes in the parameter or event underlying the derivative contract have already materialized). The legislative illustrations provide an indication of the type of financial assets that the EU legislator envisioned with the transferable securities notion, but do not limit the scope of the notion (supra). However, the fact that transferable securities are financial instruments means, in my view, that direct investments in the 'object of investment' cannot be covered by the term. Albeit direct investments are obviously investments, they cannot be catalogued as instruments or means for investment. ${ }^{100}$ For illustrative purposes, a far-fetched example may underscore this distinction: the public offering of assets that represent the liability of a soybean farm may require a prospectus, but the public offering of a sufficiently large batch of soybeans by the same soybean farm does not. Indeed, although soybeans and assets entailing the liability of a soybean farm both have intrinsic value, only the latter may qualify as a financial instrument (transferable security).

The other three criteria embedded in the transferable securities notion are less pivotal for the purposes of this paper. ${ }^{101}$ First, the negotiability of a security implies tradability (e.g. on a multilateral platform), ${ }^{102}$ but assets that do not entail the liability of an entity may equally be tradeable. Secondly, the fact that the securities have to be negotiable on the capital market appears to impose little, if any, restrictive conditions on the type of assets that may be included in the transferable securities notion. ${ }^{103}$ Thirdly, for our purposes, the exclusion of

100 See more in detail supra 3.2.2.

101 Although these criteria must of course be assessed in order to determine whether a certain financial asset may qualify as a transferable security, the central thesis of this paper (i.e. assets that do not represent the liability of an entity cannot be financial instruments) does not depend on them. See also supra no. 1.2. 102 European Commission, 'Q\&As on MiFID', 22, https://ec.europa.eu/info/law/ markets-financial-instruments-mifid-directive-2004-39-ec/ implementation/guidance-implementation-and-interpretation-law en. Assets that are not tradeable, for instance because they are subject to contractual restrictions on transfer, cannot qualify as transferable securities.

${ }^{103}$ MiFID II does not define the notion 'capital market'. There is also no consensus in legal scholarship on the exact interpretation of the concept. See e.g. Rüdiger Veil, 'Concept and Aims of Capital Markets Regulation' in Rüdiger Veil (ed), European Capital Markets Law (Hart Publishing 2017) 23, 23-24. Since it concerns an undefined concept to which no restrictive conditions appear to be connected, it may be assumed that this is a broader concept than the defined concept 'trading venue'. Trading venues include all regulated markets, multilateral trading facilities, and organized trading facilities (art. 4(1)(24) MiFID II). This view is supported by the Q\&A from the European Commission regarding MiFID I. This document attributes a particularly broad interpretation to the capital market concept by stating the following: "[the notion of capital market] is meant to include all contexts where buying and selling interest in securities meet." See European Commission, 'Q\&As on MiFID', 1 and 22, https://ec.europa.eu/info/ law/markets-financial-instruments-mifid-directive-2004-39-ec/ implementation/guidance-implementation-and-interpretation-law en. If this description of the capital market notion is accepted, it instruments of payment from the transferable securities notions merely reaffirms that transferable securities are instruments. ${ }^{104}$

Other EU legislation: Just as with the umbrella term financial instruments (see supra no. 3.1), not all EU financial legislation refers to MiFID II for the interpretation of the transferable securities notion. The Undertakings for Collective Investment in Transferable Securities (UCITS) Directive, for instance, employs a standalone definition of transferable securities. ${ }^{105}$ Much like the MiFID II definition, the UCITS definition is also referenced in other EU legislative acts (e.g. in the Money Market Funds Regulation). ${ }^{106}$ The UCITS Directive essentially considers all shares, securitized debt instruments, and "other negotiable securities that carry the right to acquire any such transferable securities by subscription or exchange" to be transferable securities. ${ }^{107}$ At first sight, the content of the UCITS Directive definition may appear to resemble the examples of transferable securities mentioned in the MiFID II definition. However, the UCITS definition differs from the MiFID II definition in that the mentioned components of the transferable securities notion form an exhaustive list, whereas the mentioned financial assets in MiFID II are mere examples of transferable securities. ${ }^{108}$ Furthermore, in order to qualify as transferable securities under the UCITS regime, financial assets have to meet a more detailed set of liquidity and negotiability standards. ${ }^{109}$

necessarily follows that securities cannot be traded on a market other than the capital market and that the capital market notion does not in itself impose any additional conditions on the concept of 'transferable securities'.

${ }^{104}$ MifID II does not define 'instruments of payment', the European Commission has advanced a functional interpretation: "securities which are used only for the purposes of payment and not for investment." See European Commission, 'Q\&As on MiFID', 1, https://ec.europa.eu/info/law/ markets-financial-instruments-mifid-directive-2004-39-ec/ implementation/guidance-implementation-and-interpretation-law en. The instruments of payment notion typically includes e.g. checks and bills of exchanges. The purpose for which an asset was developed is non-determinative in this context, as it is the actual usage that determines the qualification as instrument of payment. It can be seen from the VAT-judgment of the ECJ on Bitcoin that this distinction is relevant (Case C-264/14 Skatteverket $v$ David Hedquist [2015] ECLI:EU:C:2015:718, para 52). According to the Court of Justice, Bitcoin is only intended to be used as a means of payment. However, as explained by Houben, it is unlikely that this tax decision can be easily transposed to the financial law context. See Robby Houben, 'Bitcoins zijn deviezen voor btw-doeleinden, maar één zwaluw maakt de lente niet' (2016) TBH-RDC 177.

105 Art. 2(1)(n) and (7) Directive 2009/65/EC of the European Parliament and of the Council of 13 July 2009 on the coordination of laws, regulations and administrative provisions relating to undertakings for collective investment in transferable securities (UCITS) (recast) (text with EEA relevancy), OJ L 302, 17 November 2009, p. 32 (UCITS Directive).

106 See art. 2(3) Regulation (EU) 2017/1131 of the European Parliament and of the Council of 14 June 2017 on money market funds (text with EEA relevancy), OJ L 169, 30 June 2017, p. 8.

107 Art. 2(1)(n) and (7) UCITS Directive.

108 The definition in the UCITS Directive arguably also only captures a smaller set of derivative products.

109 See art. 2 Commission Directive 2007/16/EC of 19 March 2007 implementing Council Directive 85/611/EEC on the coordination of 
In any case, all financial assets mentioned in the transferable securities definition of the UCITS Directive entail a certain liability of an entity vis-à-vis the asset holder. Since the list of financial assets mentioned in the UCITS Directive definition has an exhaustive nature, this is sufficient prove of the fact that the UCITS Directive transferable securities notion does not capture assets that do not entail an entity's liability. A fortiori, the relevant level 2 legislation classifies the UCITS Directive transferable securities as financial instruments. ${ }^{110}$

US securities law: Contrary to European financial law, the US Securities Act of 1933 and the Securities Exchange Act of 1934 provide a definition for the 'security' notion. ${ }^{111}$ Naturally, the US securities notion cannot be transposed to the European context and, hence, I will only touch upon it briefly. ${ }^{112} \mathrm{Nev}$ ertheless, it is informative to make a brief detour to US law since an expansive interpretation of the US statutes has rendered it possible to bring assets that do not entail the liability of an entity under the US securities notion. Indeed, whereas the statutory definition appears to limit the US securities concept to financial assets that entail the liability of an entity, ${ }^{113}$ the US Supreme Court has extended the scope of the securities notion beyond assets that merely entail the liability of

laws, regulations and administrative provisions relating to undertakings for collective investment in transferable securities (UCITS) as regards the clarification of certain definitions (text with EEA relevancy), OJ L 79, 20 March 2007, p. 11 (Commission Directive 2007/16/EC). Art. 2 Commission Directive 2007/16/EC still refers to the no longer existing art. 1(8) Council Directive 85/611/EEC of 20 December 1985 on the coordination of laws, regulations and administrative provisions relating to undertakings for collective investment in transferable securities (UCITS), OJ L 375, 31 December 1985, p. 3 (Council Directive 85/611/EEC). The provision is nevertheless relevant for the interpretation of the definition of transferable securities contained in the UCITS Directive. That is to say, all references to Directive 85/611/EEC have to be read as references to the UCITS Directive (see art. 117 UCITS Directive). Based on the correlation table, this implies that the interpretation in art. 2 Directive 2007/16/EC remains relevant for the interpretation of art. 2(1)(n) UCITS Directive (see Annex IV to the UCITS Directive).

110 Art. 2(1) Commission Directive 2007/16/EC.

111 Securities Act of 1933 § 2(a)(1), Pub. L. No. 73-291, 48 Stat. 74 (1933), 15 USC § 77b(a)(1); Securities Exchange Act § 3, Pub. L. No. 73-291, 404 Stat. 881 (1934), 15 USC § 78c(a)(10).

112 See in the context of non-traditional assets more in detail e.g. Strategic Hub for Innovation and Financial Technology from the SEC, "Framework for "Investment Contract" Analysis of Digital Assets' (April 2019), available via https://www.sec.gov/corpfin/ framework-investment-contract-analysis-digital-assets.

113 See e.g. the definition in the Securities Act of 1933: "The term "security" means any note, stock, treasury stock, security future, securitybased swap, bond, debenture, evidence of indebtedness, certificate of interest or participation in any profit-sharing agreement, collateral-trust certificate, preorganization certificate or subscription, transferable share, investment contract, voting-trust certificate, certificate of deposit for a security, fractional undivided interest in oil, gas, or other mineral rights, any put, call, straddle, option, or privilege on any security, certificate of deposit, or group or index of securities (including any interest therein or based on the value thereof), or any put, call, straddle, option, or privilege entered into on a national securities exchange relating to foreign currency, or, in general, any interest or instrument commonly known as a "security", or any certificate of interest or participation in, temporary or interim certificate for, receipt for, guarantee of, or warrant or right to subscribe to or purchase, any of the foregoing. [own emphasis]" an entity. This has occurred through a broad interpretation of the catch-all notion 'investment contract', which is one of the securities types mentioned in the statutory definition. ${ }^{114}$ The longstanding Howey-test from the US Supreme Court determines that under US securities law a transaction or scheme has to meet the following conditions in order to qualify as an investment contract (and thus security): (i) a person invests his money; (ii) in a common enterprise; (iii) and is led to expect profits; (iv) solely from the efforts of the promoter or a third party. ${ }^{115}$ Whereas the first two conditions are almost always deemed to be satisfied, the SEC has traditionally focused on the assessment of the last two conditions. ${ }^{116}$ Since a reasonable expectation of profits derived from efforts of others does not imply that the considered asset entails the liability of an entity, the US securities notion does not necessarily require that an asset entails the liability of an entity. In this respect, US law fundamentally differs from EU law, which works with the umbrella notion of financial instruments (supra).

\subsubsection{Other types of financial instruments}

As mentioned above, in addition to transferable securities, the list of financial instruments in MiFID II includes money market instruments, units in collective investment undertakings, certain derivatives, and certain emission allowances. To my understanding, these assets all entail the liability of an entity vis-à-vis the holder of the asset. Money market instruments, for instance, are defined as "those classes of instruments which are normally dealt in on the money market, such as treasury bills, certificates of deposit and commercial papers and excluding instruments of payment". ${ }^{117}$ Just as with transferable secu-

114 See supra footnote 113

115 SEC v. W.J. Howey Co., et al., 328 U.S. 293 (US Supreme Court 1946), at 298-299.

116 Strategic Hub for Innovation and Financial Technology from the SEC, "Framework for "Investment Contract" Analysis of Digital Assets' (April 2019), available via https://www.sec.gov/corpfin/ framework-investment-contract-analysis-digital-assets.

117 Art. 4(1)(17) MiFID II. This MiFID-definition imposes less restrictive conditions than the definitions provided in certain other EU legislative acts. See, for instance, the definition of money market instruments in art. 2(1)(o) Directive 2009/65/EC of the European Parliament and of the Council of 13 July 2009 on the coordination of laws, regulations and administrative provisions relating to undertakings for collective investment in transferable securities (UCITS) (recast) (text with EEA relevancy), OJ L 302, 17 November 2009, p. 32 (Directive 2009/65/EC): "instruments normally dealt in on the money market which are liquid and have a value which can be accurately determined at any time". The phrase "instruments normally dealt in on the money market" is further clarified in art. 3 Commission Directive 2007/16/EC of 19 March 2007 implementing Council Directive 85/611/EEC on the coordination of laws, regulations and administrative provisions relating to undertakings for collective investment in transferable securities (UCITS) as regards the clarification of certain definitions (text with EEA relevancy), OJ L 79, 20 March 2007, p. 11 (Directive 2007/16/EC). In particular, this article provides that any reference to "instruments normally dealt in on the money market" must be understood as a reference to: (a) financial instruments admitted to or dealt in on a regulated market in accordance with art. 19(1)(a), (b), and (c) Council Directive 85/611/EEC of 20 December 1985 on the coordination of laws, regulations and administrative provisions relating to undertakings for collective 
rities, the listed examples do not limit the scope of the concept and the relevant market (i.e. money market) has not been defined. ${ }^{118}$ However, as with transferable securities, the term 'instruments' seems to mean that assets that do not entail the liability of an entity vis-à-vis the asset holder fall beyond the scope of the concept. The other mentioned instruments equally appear to refer to the representation of the liability of an entity. A unit in a collective investment undertaking, for example, entails a well-defined liability of the collective investment undertaking towards the investor holding the unit. Similarly, a derivative contract entails a contingent liability of the counterparty to the contract, which may or may not accumulate value over time, depending on the fluctuation of the parameter underlying the contract. Finally, emission allowances entail the transferable right to emit one metric tonne of carbon dioxide (or an amount of another greenhouse gas with an equivalent global-warming capacity) during a specified period, which is mirrored by the liability of the government to not penalize a polluter holding sufficient emission allowances. ${ }^{119}$

investment in transferable securities (UCITS), OJ L 375, 31 December 1985, p. 3 (Directive 85/611/EEC); and (b) financial instruments which are not admitted to trading. Although the wording of art. 3 Directive 2007/16/EC only appears relevant for the interpretation of the no longer existing art. 1(9) Directive 85/611/EEC, the provision is nevertheless relevant for the interpretation of the definition of money market instruments contained in art. 2(1)(o) Directive 2009/65/EC. Indeed, all references to Directive 85/611/EEC must be read as references to Directive 2009/65/EC (see art. 117 Directive $2009 / 65 / E C$ ). Based on the correlation table, this implies that the interpretation in art. 3 Directive 2007/16/EC of the notion "instruments normally dealt in on the money market" from art. 1(9) Directive 85/611/EEC remains relevant for the interpretation of art. 2(1)(o) Directive 2009/65/EC (see art. 117 in conjunction with Annex IV Directive 2009/65/EC). See in this context also art. 2(2) Regulation (EU) 2017/1131 of the European Parliament and of the Council of 14 June 2017 on money market funds (text with EEA relevancy), OJ L 169, 30 June 2017, p. 8.

118 Cf. supra footnote 117 for guidance on the concept in other EU legislative documents. The money market is typically distinguished from the capital market on the basis of the (remaining) maturity of the traded instruments (e.g. remaining maturity of one year). Conceptually, the MiFID II definition of money market instruments leaves the reader with little comfort. In fact, the circular text of the Directive merely states that money market instruments are instruments that are traded on the money market. The European Commission is more pragmatic and has asserted that money market instruments are tradable liquid debt instruments. See European Commission, 'Q\&As on MiFID', 41, https://ec.europa.eu/info/ law/markets-financial-instruments-mifid-directive-2004-39-ec/ implementation/guidance-implementation-and-interpretation-law en.

119 Art. 3(a), (b), and (j) Directive 2003/87/EC of the European Parliament and of the Council of 13 October 2003 establishing a system for greenhouse gas emission allowance trading within the Union and amending Council Directive 96/61/EC (text with EEA relevancy), OJ L 27525 October 2003, p. 32. See also art. 16 of the Directive mentioned in this footnote.

\subsection{Intermediate conclusion}

The preceding paragraphs have tentatively explored whether there exists a common conceptual denominator that is shared by all financial assets that are subject to EU financial legislation. I find that the financial assets subject to EU financial legislation all entail the liability of an entity. Different from the situation in the US, it would be unprecedented to interpret the current scope of application of major EU financial legislation as including assets that do not entail the liability of an entity. Moreover, such reading would be exceedingly hard to reconcile with the notion of financial instruments. Since all assets that entail the liability of an entity have intrinsic value, EU financial law does not govern assets that only have extrinsic value. It follows from this observation that inter alia Bitcoin, Ether, Ripple, Bitcoin Cash, Bitcoin SV, EOS, Litecoin, Binance Coin, and Tez are currently not subject to EU financial legislation. ${ }^{120}$

The results presented in this paper are in line with the general findings of the European Commission and the EU regulatory agencies that many non-traditional financial assets fall beyond the scope of EU financial legislation and, accordingly, are not subject to inter alia EU rules on consumer or investor protection and market integrity. ${ }^{121}$ Nevertheless, as rightly pointed out by the European Commission in a recent consultation document, the absence of a consensus on the exact conditions under which novel asset types may qualify as financial instruments in the sense of MiFID II, may create legal uncertainty for market participants. ${ }^{122}$ In my view and as illustrated by the analysis of the EU financial asset definitions in the previous sections, this legal uncertainty originates to a large extent from the circularity of EU financial asset definitions. By aiming to identify the common conceptual denominator of the financial instruments notion, this paper seeks to provide a conceptual rationale for the findings of the EU

120 Cf. supra no. 2.3.1, where it was argued that these assets do not entail the liability of an entity and have no intrinsic value.

${ }^{121}$ European Commission, 'Consultation document on an EU framework for markets in crypto-assets' (December 2019) 4, available at https://ec.europa.eu/info/sites/info/files/ business_economy_euro/banking_and_finance/documents/ 2019-crypto-assets-consultation-document_en.pdf. Cf. ESMA, 'Advice: Initial Coin Offerings and Crypto-Assets' (9 January 2019), available via https://www.esma.europa.eu/sites/ default/files/library/esma50-157-1391_crypto_advice.pdf; EBA, 'Report with advice for the European Commission on cryptoassets' (9 January 2019), available via https://eba.europa.eu/ documents/10180/2545547/EBA+Report+on+crypto+assets.pdf;

FCA, 'Guidance on Cryptoassets: Feedback and Final Guidance to CP 19/3' (Policy Statement PS19/22, July 2019), available via https://www.fca.org.uk/publications/policy-statements/ ps19-22-guidance-cryptoassets.

122 European Commission, 'Consultation document on an EU framework for markets in crypto-assets' (December 2019) 7-8, available at https://ec.europa.eu/info/sites/info/files/ business_economy_euro/banking_and_finance/documents/ 2019-crypto-assets-consultation-document_en.pdf. 
regulatory agencies that most non-traditional assets are not subject to contemporary EU law.

\subsection{Policy implications}

In recent years, national, international, and supranational regulators and supervisors have paid close attention to the proliferation and rapid evolution of the different types of nontraditional financial assets. ${ }^{123}$ Although no consensus exists, many policymakers appear to be convinced that the risks related to many of the emerging non-traditional assets warrant the subjection of these assets to (financial) regulation. ${ }^{124}$ This was e.g. illustrated by policymakers' responses to the 2019 announcement that plans existed for conceiving the abovediscussed Libra system (see more in detail on Libra supra no. 2.1). ${ }^{125}$

This paper does not seek to address the desirability of legislation or regulation in the emerging markets for nontraditional assets or how such regulation, if any, should look like. However, the intermediate conclusion discussed above (supra no. 3.3), appears highly relevant to this policy debate. That is to say, if the thesis defended in this paper is indeed correct, this would mean that most non-traditional financial assets fall beyond the scope of application of major EU finan-

${ }^{123}$ Cf. e.g. Sharon Brown-Hruska and Trevor Wagener, 'The virtual currency regulatory framework in global context' (2018) 13 CMLJ 487-517.

124 See e.g. FCA, 'Guidance on Cryptoassets' (Consultation Paper CP19/3, January 2019) 11 et seq., available via https://www.fca.org. uk/publication/consultation/cp19-03.pdf

125 See e.g. Tom Wilson, 'Bitcoin tumbles as U.S. senators grill Facebook on crypto plans' (Reuters, 16 July 2019), available via https://www.reuters.com/article/us-crypto-currencies/ bitcoin-tumbles-as-u-s-senators-grill-facebook-on-crypto-plansidUSKCN1UB24T ? feedType=nl\&feedName=businessNews\&utm source=Sailthru\&utm_medium $=$ email\&utm_campaign $=2018 \%$ 20Template:\%20US\%20Business\%20News\%201700\%207/1/19\% 20-\%207/31/19\%202019-07-16\&utm_term=2018\%20-\%20US\% 20Business\%201700; Pete Schroeder and Katie Paul, 'Facebook should not be trusted with 'crazy' cryptocurrency plan: senators' (Reuters, 16 July 2019), available via https: //www.reuters.com/article/us-facebook-cryptocurrency-senate/ facebook-should-not-be-trusted-with-crazy-cryptocurrencyplan-senators-idUSKCN1UB174? feedType $=$ nl\&feedName $=$ businessNews\&utm_source=Sailthru\&utm_medium= email\&utm_campaign=2018\%20Template:\%20US\% 20Business\%20News\%201700\%207/1/19\%20-\%207/31/19\% 202019-07-16\&utm_term $=2018 \% 20-\% 20$ US\%20Business\% 201700; Huw Jones, 'Facebook's Libra coin closely watched by authorities: FSB' (Reuters, 25 June 2019), available via https:/www.reuters.com/article/us-g20-fsb/ facebooks-libra-coin-closely-watched-by-authorities-fsb-

idUSKCN1TQ1Z5; Huw Jones, David Milliken, Brenna Hughes Neghaiwi, 'European watchdogs demand detail on Facebook's cryptocurrency' (Reuters, 25 June 2019), available via https://www.reuters.com/article/us-facebook-crypto/ european-watchdogs-demand-detail-on-facebooks-

cryptocurrency-idUSKCN1TQOYR. See, however, also: Question for written answer Z-000040/2019 to the European Central Bank, Eva Kaili, available via http://www.europarl.europa.eu/ doceo/document/ECON-QZ-639928_EN.pdf. cial legislation. Hence, if policymakers indeed find it necessary or appropriate to mitigate the risks related to non-traditional financial assets, legislative or regulatory intervention will be required. Against this backdrop, the European Commission is currently examining whether a common regulatory approach at the EU level could be appropriate inter alia in the fields of consumer or investor protection and market integrity. ${ }^{126}$ In any case, the large majority of the stakeholders consulted by the European Commission appear to agree that the absence of a common approach with regard to the qualification of nontraditional assets as financial instruments may constitute an impediment to the further development of non-traditional financial assets and their markets. ${ }^{127}$

Although the proposition defended in this paper points toward legislative or regulatory intervention if policymakers deem such intervention appropriate, it does not allow to determine whether such intervention would be efficient. This paper essentially submits that EU financial legislation does not cover assets with only extrinsic value, including most novel types of financial assets, since these assets cannot entail the liability of an entity. This exclusion from EU financial legislation is based upon conceptual considerations, but from a more practical perspective it would arguably also be hard, if not impossible, to apply many of the EU legislative acts to assets that do not entail the liability of an entity. More specifically, the application of many rules in EU financial legislation presume the existence of a bilateral relationship between parties, which creates rights and liabilities. It is, for example, unclear how the prospectus regime could be applied to assets that have no identifiable issuer. Nevertheless, there appear to be good reasons to worry e.g. about investor or consumer protection and market integrity in the markets for non-traditional financial assets. Hence, (tailor-made) legislation and regulation that does not depend on the rights and liabilities that an asset may entail vis-à-vis another party appears the most appropriate venue of future legislative or regulatory intervention.

\section{Legal conceptions of money}

This paper has argued that EU financial law only governs assets that entail the liability of an entity. Against this backdrop, this paper has drawn a distinction between assets that have intrinsic value and assets that only have extrinsic value. In this section, I examine whether such distinction may also be useful for the monetary analysis of newly emerging financial assets.

${ }^{126}$ European Commission, 'Consultation document on an EU framework for markets in crypto-assets' (December 2019) 4-5, available at https://ec.europa.eu/info/sites/info/files/ business_economy_euro/banking_and_finance/documents/ 2019-crypto-assets-consultation-document_en.pdf.

127 See the responses to question 59 of the European Commission consultation mentioned in footnote 126: https://ec. europa.eu/info/law/better-regulation/have-your-say/initiatives/ 12089-Directive-regulation-establishing-a-European-frameworkfor-markets-in-crypto-assets/public-consultation. 
Unless otherwise stipulated by law or agreement, euro notes and coins are the only legal tender in the Eurozone. ${ }^{128}$ Consequently, a debtor can in principle not force his creditor to accept a payment method other than a cash payment. This principle also applies to payments that are executed through any type of non-traditional asset: a debtor cannot force his creditor to accept e.g. Bitcoin, Ether, or Tether, regardless of whether these assets entail the liability of an entity or not.

However, there exist theories that advocate broader legal conceptualizations of money. Rather than based on legislative acts, these theories are often inspired by asset properties and functionalities that the respective authors deem necessary to speak of money. In the following paragraphs, I briefly sketch the central ideas that underlie the different money theories and their relationship to novel forms of assets. ${ }^{129}$ In any case, the legal conceptions of money do not necessarily correspond to the meaning of the word 'money' in everyday language or economic jargon. ${ }^{130}$

\subsection{Legal theories of money}

\subsubsection{The state theory}

One strand in legal scholarship essentially argues that only the items that are accepted as payment by the state constitute money. ${ }^{131}$ Although Mann's renowned book (Mann on the Legal Aspect of Money) ${ }^{132}$ is often cited as the main advocate of the state theory of money, Mann's money concept is limited to legal tender issued by the state. ${ }^{133}$ In the actual state theory of money, the notion of money is only limited by the requirement that the state must accept the relevant medium as payment, ${ }^{134}$ which means that the money must not necessarily be issued by the state. In any case, regardless of intrinsic or extrinsic asset value, newly developed assets do not qualify as money in either interpretation of the state theory of money. ${ }^{135}$ However, future innovative public policy may bring some of these assets within the scope of the state theory of money. In

${ }^{128}$ Art. 128 Consolidated version of the Treaty on the Functioning of the European Union, OJ C 326, 26 October 2012, p. 47.

129 See for a more comprehensive overview of the different theories of money e.g. Niels Vandezande, Virtual Currencies: A Legal Framework (Intersentia 2018) 141-154; Charles Proctor, Mann on the Legal Aspect of Money (Oxford University Press 2012) 15-30.

${ }^{130}$ In order to be able to speak of money in economic terms, it is traditionally required that the relevant medium (i) is a generally accepted means of exchange; (ii) preserves purchase power; and (iii) acts as a unit of account.

${ }^{131}$ Georg Friedrich Knapp, The State Theory of Money (Macmillan 1924) 24.

132 Initially, Mann's standard work was known under a different title. See, for example, the 1982 version of the book: Frederick Alexander Mann, The Legal Aspect of Money (Oxford University Press 1982). However, in the more recent versions that were published after Mann's death in 1991, the surname of the book's intellectual father has been included in the title: Charles Proctor, Mann on the Legal Aspect of Money (Oxford University Press 2012).

133 See Charles Proctor, Mann on the Legal Aspect of Money (Oxford University Press 2012) 15.

134 Georg Friedrich Knapp, The State Theory of Money (Macmillan 1924) 24.

135 Cf. Niels Vandezande, Virtual Currencies: A Legal Framework (Intersentia 2018) 144-146. recent years, for instance, central banks have increasingly examined the potency of so-called digital currencies as a new form of digital central bank money (see supra footnote 30 ).

\subsubsection{The societal theory}

The societal theory of money rejects the notion that the actions of the state determine what can be regarded as money. Instead, it posits that the social consensus defines what should legally be regarded as money. ${ }^{136}$ Hence, the public acceptance and use of a certain item as a means of payment determines that item's legal status as money within a society. ${ }^{137}$ Although one may argue that it would be desirable to let the societal consensus determine what constitutes money, there appears to be no legal basis for this theory. ${ }^{138}$ A social consensus criterion also seems hard to work with from a legal point of view, as there exist no well-defined parameters to decide on the degree of social consensus that would have to be reached. ${ }^{139}$ I am tempted to think that there is currently no social consensus on the acceptance of any of the newly developed assets as money, ${ }^{140}$ but, as stated, objective parameters are absent. Hence, one could very well argue the opposite. In any case, just as the state theory of money, the societal theory of money functions independently from the asset categorization that I have suggested in this paper.

\subsubsection{The institutional theory}

The institutional theory of money argues that money is no more than a specific sort of claim against a debtor, whose public acceptance as a means of payment and purchase power preservation depends on the presence of a legal framework that, among other things, aims to guarantee the value of the claim. ${ }^{141}$ This theory is closely linked to the conventional and unconventional powers of central banks to conduct monetary policy and implies that the money supply has to be controlled by the central bank. ${ }^{142}$ Through money creation, a central bank can control the money base, and if it properly ac-

136 Arthur Nussbaum, Money in the Law: National and International. A Comparative Study in the Borderline of Law and Economics (Foundation Press 1950) 8.

137 Charles Proctor, Mann on the Legal Aspect of Money (Oxford University Press 2012) 23-24.

138 In this respect the societal theory of money differs from the state theory of money, which has a constitutional basis in many jurisdictions. Cf. Rosa Lastra, International Financial and Monetary Law (Oxford University Press 2015) 15-16.

139 Similarly, it is unclear what network of users could be deemed to amount to a 'society'.

140 See for example otherwise: US District Court Eastern District of Texas 6 August 2013, SEC v. Trendon T. Shavers and Bitcoin Savings and Trust, Case no. 4:13-CV-416, where the mere possibility to use Bitcoin as money and exchange it for conventional currencies was deemed sufficient to qualify Bitcion as a currency or form of money. See more in detail on this decision: Niels Vandezande, Virtual Currencies: A Legal Framework (Intersentia 2018) 152.

141 Antonio Sáinz de Vicuña, 'An Institutional Theory of Money' in Mario Giovanoli and Diego Devos (eds), International Monetary and Financial Law (Oxford University Press 2010) 517, 517.

142 Antonio Sáinz de Vicuña, 'An Institutional Theory of Money' in Mario Giovanoli and Diego Devos (eds), International Monetary and Financial Law (Oxford University Press 2010) 517, 525. Although central banks are now typically public institutions, in the institutional theory of money - unlike in the state theory of money - they could 
counts for 'private money creation' by commercial banks, ${ }^{143}$ the central bank will also have control over the money supply (i.e. the total amount of 'money' available in the economy). ${ }^{144}$ In other words, in the institutional theory of money, the legal foundations of the institutional framework ensure that a certain type of claim can be regarded as money.

According to the institutional theory of money, money consists of claims on issuing central banks and claims on commercial banks (the latter in the form of deposits that are held by the public and are repayable on demand). ${ }^{145}$ This type of claims on commercial banks is seen as an indirect claim on the issuing central bank since the claim can be converted at any time into banknotes, which are a direct claim on the central bank. ${ }^{146}$ In the Eurozone, the following items would qualify as money under the institutional theory of money. First, all euro banknotes issued by the European Central Bank (ECB) or Eurozone national central banks are legally and technically a claim on a central bank, ${ }^{147}$ which constitutes money. Secondly, a credited deposit account held by a commercial bank with the central bank also creates a claim on the central bank that qualifies as money. ${ }^{148}$ Finally, as explained above, the claims of depositors against their commercial banks equally qualify as money in the institutional theory of money. At the time of writing, none of the novel types of assets can be categorized as money under the institutional theory of money. However, according to the institutional theory of money, only assets that entail the liability of an entity can qualify as money. Assets with only extrinsic value can never qualify as money.

\subsubsection{The credit theory}

Similar to the institutional theory of money, the credit theory of money-founded by Innes-views money as a claim on an

also be private institutions. See Antonio Sáinz de Vicuña, ibid, 531532.

${ }^{143}$ I.e. if the central bank takes into account the monetary transmission mechanisms through which 'private' money is created within commercial banks.

144 See, for example, Freddy Heylen, Macro-economie (Garant 2014) 292. Traditionally, the money supply refers to all currency in circulation and various kinds of deposits held by the public at commercial banks. See Freddy Heylen, ibid, 290.

145 Charles Proctor, Mann on the Legal Aspect of Money (Oxford University Press 2012) 27; Antonio Sáinz de Vicuña, 'An Institutional Theory of Money' in Mario Giovanoli and Diego Devos (eds), International Monetary and Financial Law (Oxford University Press 2010) 517, 523.

146 Antonio Sáinz de Vicuña, 'An Institutional Theory of Money' in Mario Giovanoli and Diego Devos (eds), International Monetary and Financial Law (Oxford University Press 2010) 517, 523.

147 Art. 3(3) Decision of the European Central Bank of 13 December 2010 on the issue of euro banknotes (recast) (ECB/2010/29) (2011/67/EU), OJ L 9 February 2011, p. 35, 26. Both the ECB and the Eurozone national central banks are entitled to issue euro banknotes (see art. 2 of the aforementioned Decision). Typically, these claims on the central bank do not have a maturity, nor are they ever payable. Cf. Antonio Sáinz de Vicuña, 'An Institutional Theory of Money' in Mario Giovanoli and Diego Devos (eds), International Monetary and Financial Law (Oxford University Press 2010) 517, 523. 148 Antonio Sáinz de Vicuña, 'An Institutional Theory of Money' in Mario Giovanoli and Diego Devos (eds), International Monetary and Financial Law (Oxford University Press 2010) 517, 523. entity or a "token of indebtedness". ${ }^{149}$ However, unlike the institutional theory of money, the credit theory of money does not require money to be a debt instrument issued by a public institution. Innes does not impose any 'additional' criteria to the issued debt instrument: "Money [...] is credit and nothing but credit. A's money is B's debt to him, and when B pays his debt, A's money disappears. This is the whole theory of money." 150 Hence, a debt instrument issued by a private actor may just as well be regarded as money, as long as "the giver acknowledges his obligation to take [the token of indebtedness] back in payment of a debt due". ${ }^{151}$ By regarding the issuance of a debt instrument pivotal to the money concept, the credit theory of money aims to reject the notion that coins derive their value from the precious metals that may be linked to them, as was e.g. the case with the gold standard. ${ }^{152}$ Nowadays this notion may seem self-evident, but until the beginning of the twentieth century this was by no means a generally accepted point of view. According to the credit theory of money, money issued by the government creates a debt of the issuing government vis-à-vis the entity holding the money. More specifically, money issuance by the government implies the government's obligation to accept the issued money as payment for the satisfaction of any due debt towards the government (e.g. taxes that are due). ${ }^{153}$ Under the credit theory of money, novel asset types that entail the liability of an entity would qualify as money. On the contrary, assets that have only extrinsic asset value, such as Bitcoin, cannot qualify as money in the credit theory of money. ${ }^{154}$

\subsection{Electronic money}

The Second Electronic Money Directive requires EU member states to prohibit natural or legal persons who have not been authorized as electronic money issuers from issuing electronic money (e-money). ${ }^{155}$ Electronic money is defined as any electronically stored monetary value that (i) is represented by a claim on the issuer; (ii) has been issued in exchange of funds for the purpose of making payment transactions $;{ }^{156}$ and (iii) is

149 Alfred Mitchell Innes, 'What is Money?' (1913) 30 Banking LJ 377, 402. See for an authoritative review of this paper: John Maynard Keynes, 'What is Money? By Mitchell Innes' (1914) 24 EJ, 419. 150 Alfred Mitchell Innes, 'What is Money?' (1913) 30 Banking LJ 377, 402.

151 Alfred Mitchell Innes, 'What is Money?' (1913) 30 Banking LJ $377,402$.

152 Alfred Mitchell Innes, 'What is Money?' (1913) 30 Banking LJ 377, 379.

153 Alfred Mitchell Innes, 'What is Money?' (1913) 30 Banking LJ 377,402

154 Contra Niels Vandezande, Virtual Currencies: A Legal Framework (Intersentia 2018) 157.

155 Art. 10 Directive 2009/110/EC of the European Parliament and of the Council of 16 September 2009 on the taking up, pursuit and prudential supervision of the business of electronic money institutions amending Directives 2005/60/EC and 2006/48/EC and repealing Directive 2000/46/EC (text with EEA relevancy), OJ L 26710 October 2009, p. 7 (hereinafter: Second Electronic Money Directive). 156 For the definition of the term 'payment transactions', the Second Electronic Money Directive still refers Directive 2007/64/EC of the European Parliament and of the Council of 13 November 2007 on payment services in the internal market amending Di- 
accepted by entities other than the electronic money issuer. ${ }^{157}$ Hence, the categorization suggested in this paper based on asset value is also valuable in this context. Novel assets that have only extrinsic value, such as Bitcoin and Litecoin, can never qualify as electronic money because they do not represent the liability of an issuer. ${ }^{158}$ Consequently, all rules that are connected to the concept of electronic money cannot be applied to this type of assets. ${ }^{159}$ On the other hand, assets that represent the liability of an entity (e.g. Libra) may be covered if all conditions from the electronic money definition are met. If this is the case, the relevant entity will have to obtain an authorization as electronic money institution to carry out activities involving electronic money. ${ }^{160}$

\subsection{Payment services}

In principle, the Second Payment Services Directive (PSD II) requires EU member states to bar EU undertakings from providing payment services, unless they have obtained authorization as a payment institution prior to the commencement of the provision of payment services. ${ }^{161}$ The notion payment services refers to (i) [s]ervices enabling cash to be placed on a payment account as well as all the operations required for operating a payment account; (ii) [s] ervices enabling cash withdrawals from a payment account as well as all the operations required for operating a payment account; (iii) [e]xecution of payment transactions, including transfers of funds on a payment account with the user's payment service provider or with another payment service provider ;162 (iv) [e]xecution of payment transactions where the funds are covered by

rectives 97/7/EC, 2002/65/EC, 2005/60/EC and 2006/48/EC and repealing Directive 97/5/EC (text with EEA relevancy), OJ L 319, 5 December 2007, p. 1 . This directive has been replaced by Directive (EU) 2015/2366 of the European Parliament and of the Council of 25 November 2015 on payment services in the internal market, amending Directives 2002/65/EC, 2009/110/EC and 2013/36/EU and Regulation (EU) No 1093/2010, and repealing Directive 2007/64/EC (text with EEA relevancy), OJ L 337, 23 December 2015, p. 35. Art. 4(5) of this directive defines a payment transaction as "an act, initiated by the payer or on his behalf or by the payee, of placing, transferring or withdrawing funds, irrespective of any underlying obligations between the payer and the payee".

157 Art. 2(2) Second Electronic Money Directive.

158 Cf. Robby Houben, 'Bitcoin: there are two sides to every coin' (2015) TBH-RDC 139, 157.

159 Cf. EBA, 'Report with advice for the European Commission on crypto-assets' (9 January 2019), 13-14, available via https://eba.europa.eu/documents/10180/2545547/EBA+Report+ on+crypto+assets.pdf.

160 Cf. EBA, 'Report with advice for the European Commission on crypto-assets' (9 January 2019), 14, available via https://eba.europa.eu/documents/10180/2545547/EBA+Report+ on+crypto+assets.pdf.

161 Art. 11(1) Directive (EU) 2015/2366 of the European Parliament and of the Council of 25 November 2015 on payment services in the internal market, amending Directives 2002/65/EC, 2009/110/EC and 2013/36/EU and Regulation (EU) No 1093/2010, and repealing Directive 2007/64/EC (text with EEA relevancy), OJ L 337, 23 December 2015, p. 35 (hereinafter: PSD II).

162 In particular: "(a) execution of direct debits, including one-off direct debits; (b) execution of payment transactions through a payment card or a similar device; (c) execution of credit transfers, including standing orders." a credit line for a payment service user $;^{163}$ (v) [i]ssuing of payment instruments and/or acquiring of payment transactions; (vi) [m]oney remittance; (vii) [p]ayment initiation services; and (viii) [a]ccount information services". ${ }^{164}$ All components of this enumeration refer indirectly to the defined notion of 'funds'. ${ }^{165}$ In PSD II, 'funds' refers to banknotes, coins, scriptural money, ${ }^{166}$ or electronic money as defined in the Second Electronic Money Directive. ${ }^{167}$ In order to speak of funds in the meaning of PSD II, it is thus required that the considered assets represent the liability of an entity. Consequently, non-traditional assets that have only extrinsic value, such as Bitcoin and Litecoin, cannot qualify as funds in the sense of PSD II because they do not represent the liability of an issuer. Assets that represent the liability of an entity, on the other hand, may under certain circumstances be covered by the funds and payment services notions.

\section{Conclusion}

As a complement to the asset categorizations that are based on the technologies or functionalities underpinning nontraditional asset types, this paper has proposed a novel systematization of non-traditional assets that is based upon asset value. More specifically, this paper has submitted that, irrespective of underlying technologies and functionalities, all assets that are subject to major EU financial legislation have a conceptual common denominator: they entail the liability of an entity and, hence, have intrinsic value. Narrative evidence construed around the financial instrument notion from MiFID has illustrated that EU financial law has historically not encapsulated assets that do not entail an entity's liability within its scope of application. More fundamentally, the

163 In particular: "(a) execution of direct debits, including one-off direct debits; (b) execution of payment transactions through a payment card or a similar device; (c) execution of credit transfers, including standing orders."

164 Art. 4(3) juncto Annex I PSD II.

165 The first two elements of the enumeration refer to the notion 'payment account'. Payment account in turn refers to the notion 'payment transaction', which is "an act, initiated by the payer or on his behalf or by the payee, of placing, transferring or withdrawing funds, irrespective of any underlying obligations between the payer and the payee ([added emphasis]". See art. 4(12) and (5) PSD II. The third and fourth component of the enumeration also refer to payment transactions. The fifth element in the enumeration refers to the acquisition of payment transactions and/or issuance of payment instruments. The latter concept refers to the initiation of payment orders, which in turn references payment transactions. See art. 4(14) and (13) PSD II. Money remittances also refer to funds (see art. 4(22) PSD II). The last two elements of the enumeration (i.e. payment initiation services and account information services) refer to the term 'payment account' and thus indirectly reference the funds notion. See art. 4(15) and (16) PSD II.

166 Scriptural money refers to deposit balances held at a commercial or central bank, or electronic money. See ECB CryptoAssets Task Force, 'Crypto-Assets: Implications for financial stability, monetary policy, and payments and market infrastructures' (ECB Occasional Paper Series no. 223, May 2019) 8 (footnote 14), available at https://www.ecb.europa.eu/pub/pdf/scpops/ ecb.op223 3ce14e986c.en.pdf.

167 Art. 4(25) PSD II. 
umbrella term for the financial assets within the scope of EU financial legislation (i.e. financial instruments) reveals that EU financial law exclusively governs the means or instruments through which the investment in an underlying investment object is made possible.

The systematization of non-traditional assets proposed in this paper is no panacea for interpretational issues in relation to the financial assets within the scope of EU financial legislation. That is to say, the observation that a certain asset entails the liability of an entity and thus has intrinsic value is insufficient to conclude that the asset is governed by EU financial law. However, the proposed categorization sheds light on a group of assets that are definitely not covered by EU financial law: assets that only have extrinsic value. From this perspective, the proposed categorization is complementary to existing categorizations that focus on the functionalities of non-traditional assets. By employing an objective parameter, the suggested categorization allows to eradicate ambiguities and potential overinclusiveness of functionality-based categorizations of non-traditional assets. When applied to the ten non-traditional assets with the largest market capitalization as listed on CMC, I find that nine out of ten applications (i.e. Ether, Ripple, Bitcoin Cash, Bitcoin SV, EOS, Litecoin, Binance Coin, and Tez) fall beyond the scope of EU financial legislation.
Only one of the listed assets entails the liability of an entity and may thus fall within the scope of EU financial legislation (i.e. Tether). In an analysis of the different legal conceptualizations of money, the categorization proposed in this paper may prove relevant only under the institutional and credit theory of money. The state and societal theory of money function independently from the asset categorization that has been suggested in this paper.

This paper has not addressed the desirability of adequate investor protection in the emerging markets for nontraditional assets. However, this paper has aimed to show that it would be unprecedented to interpret the current scope of application of major EU financial legislation as including assets that do not entail the liability of an entity. Moreover, such reading would be exceedingly hard to reconcile with the notion of financial instruments. Hence, if the EU legislator deems it necessary to subject non-traditional assets that do not entail the liability of an entity to a legislative and regulatory framework, legislative intervention is warranted.

\section{Declaration of Competing Interest}

